Required software to e-Annotate PDFs: Adobe Acrobat Professional or Adobe Reader (version 11 or above). (Note that this document uses screenshots from Adobe Reader DC.)

The latest version of Acrobat Reader can be downloaded for free at: http://get.adobe.com/reader/

Once you have Acrobat Reader open on your computer, click on the Comment tab (right-hand panel or under the Tools menu).

This will open up a ribbon panel at the top of the document. Using a tool will place a comment in the right-hand panel. The tools you will use for annotating your proof are shown below:

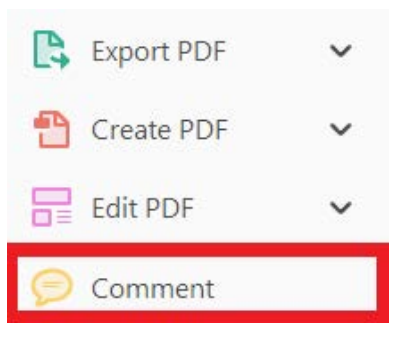

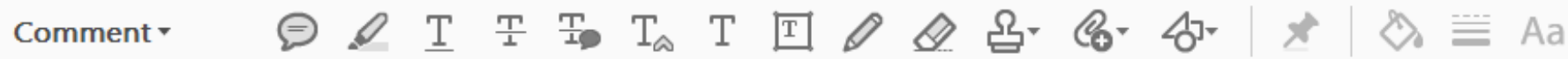

1. Replace (Ins) Tool - for replacing text.

T. Strikes a line through text and opens up a text box where replacement text can be entered.

How to use it:

- Highlight a word or sentence.

- Click on $\frac{T}{\perp P}$

- Type the replacement text into the blue box that appears.

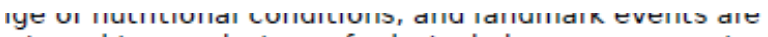
nitored in nonulations of relatively homogeneous single $n$ of secharomyes , and is initlated atter

: carbon source [ ] 1]. S:

are referred to as mei

$\mathrm{n}$ of meiosis-specific $\mathrm{s}$

inducer of meiosis) [3

I functions as a

repression, the repre

pression) and RGRI

rase II mediator subur

resem dil in

irectly or indirectly re
Reply X

staddon

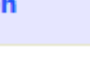

Reply $\mathbf{x}$

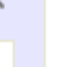

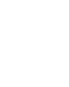

\section{SIf 05}

3. Commenting Tool - for highlighting a section to be changed to bold or italic or for general comments.

Use these 2 tools to highlight the text
where a comment is then made.

How to use it:

- Click on .

- Click and drag over the text you need to highlight for the comment you will add.

- Click on $\risingdotseq$.

- Click close to the text you just highlighted.

- Type any instructions regarding the text to be altered into the box that appears.

nformal invariance: $r$

A: Math. Gen., Vol. 12, N This needs to be bold

lified theory for a matri: 'ol. 8, 1984, pp. 305-32 ıd manuscript, 1984.

shing fractions for $\mathrm{DO} \rightarrow \mathrm{K}+\mathrm{K}$

nlation in nn Norave' Dhwe
2. Strikethrough (Del) Tool - for deleting text.

\section{T Strikes a red line through text that is to be}

How to use it:

- Highlight a word or sentence.

- Click on $\frac{T}{\perp}$.

- The text will be struck out in red.

experımental data It avallable. ror URrs to be had to meet all of the following criteria:

1. Small size (35-250 amino acids).

2. Absence of similarity to known proteins.

3. Absence of functional data which could n the real overlapping gene.

4. Greater than $25 \%$ overlap at the $\mathrm{N}$-termir terminus with another coding feature; ov $\epsilon$ both ends; or ORF containing a tRNA.

4. Insert Tool - for inserting missing text at specific points in the text.

\section{T Marks an insertion point in the text and} opens up a text box where comments can be entered.

How to use it:

- Click on $\mathrm{T}_{\boldsymbol{A}}$.

- Click at the point in the proof where the comment should be inserted.

- Type the comment into the box that appears.

Meiosis has a central role in the sexual reproduction of nearly all eukaryotes analysis of meiosis, esp jstaddon by a simple change of $n$ jeds conveniently monitored Yeast, is sin cells. Sporulation of Sat ne tyl

cell, the $\mathrm{a} / \alpha$ cell, and is of a fermentable carbor sporulation and are refe 2b]. Transcription of me meiosis, in S. cerevisiae of the

of the gene RMEI funct $\quad 05 / 05 / 2017$ 15:57
Rmelp to exert repressi of GALI gene expression) and $R G K I$ are required $[1,2,3,1]$. I nese $g \in$ 
5. Attach File Tool - for inserting large amounts of text or replacement figures.

Q. Inserts an icon linking to the attached file in the appropriate place in the text.

How to use it:

- Click on $\&$.

- Click on the proof to where you'd like the attached file to be linked.

- Select the file to be attached from your computer or network.

- Select the colour and type of icon that will appear in the proof. Click OK.

The attachment appears in the right-hand panel.

:hondrial preparatior ative daitage injury le extent of membra I, malondialdehyde ( (TBARS) formation. '

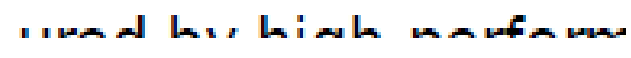

6. Add stamp Tool - for approving a proof if no corrections are required.

$\Omega=$ Inserts a selected stamp onto an appropriate place in the proof.

\section{How to use it:}

- Click on $\Omega$.

- Select the stamp you want to use. (The Approved stamp is usually available directly in the menu that appears. Others are shown under Dynamic, Sign Here, Standard Business).

- Fill in any details and then click on the proof where you'd like the stamp to appear. (Where a proof is to be approved as it is, this would normally be on the first page).

of the pusiness cycie, starting with the on perfect competition, constant ret

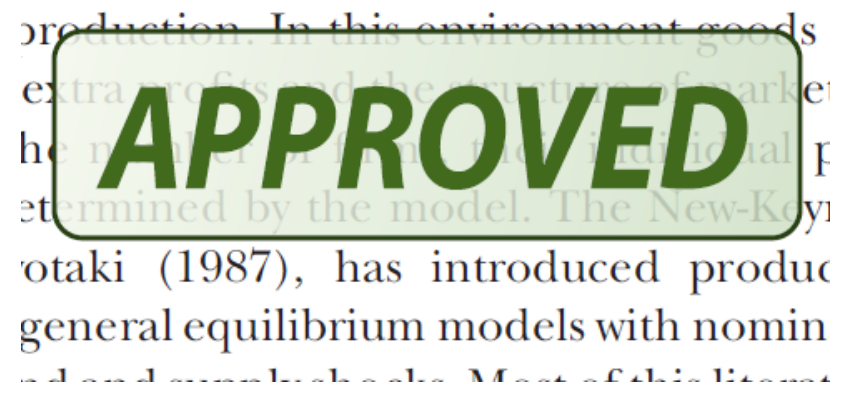

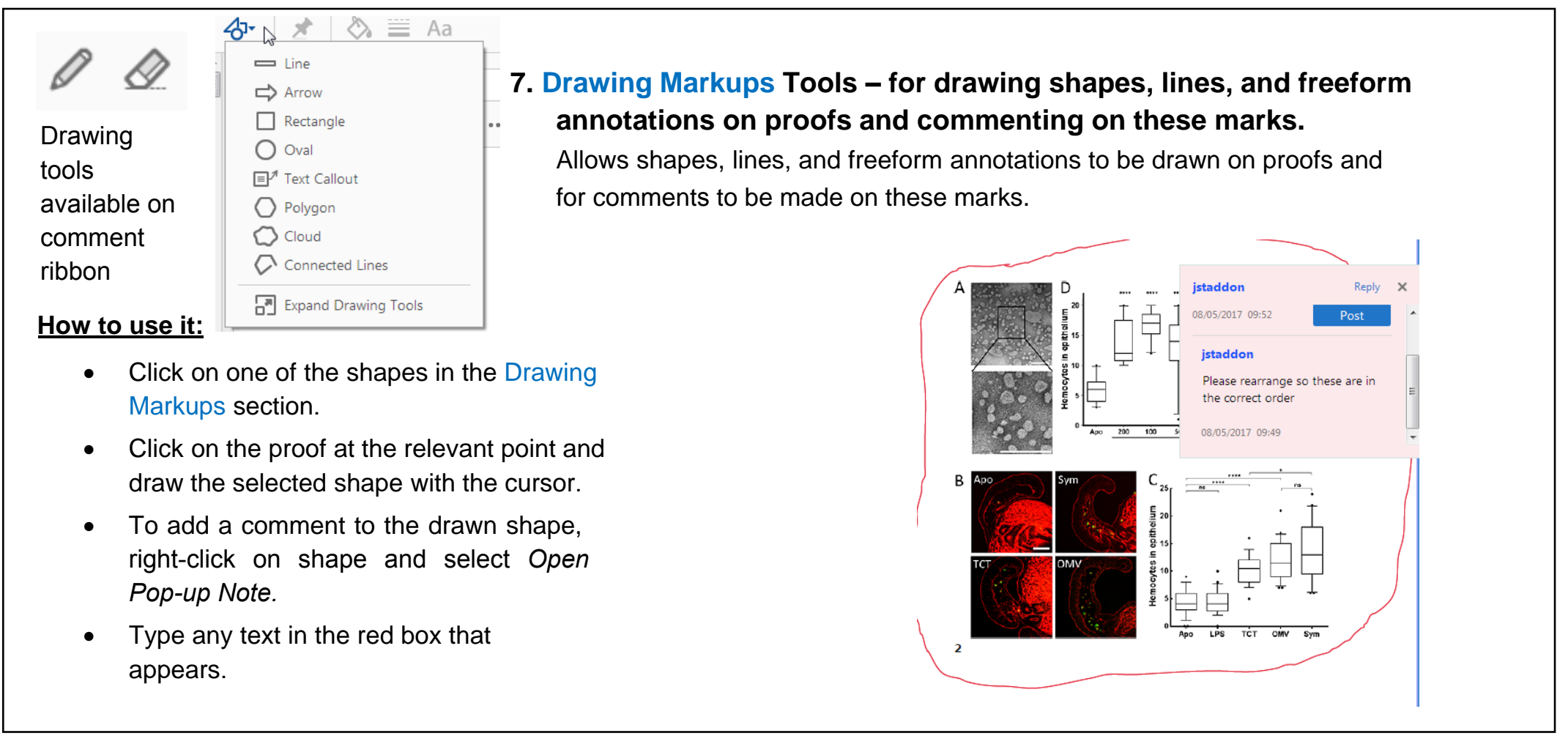

For further information on how to annotate proofs, click on the Help menu to reveal a list of further options:

\begin{tabular}{|c|c|c|}
\hline \multicolumn{3}{|l|}{ Help } \\
\hline & Online Support & $\mathrm{F} 1$ \\
\hline \multicolumn{3}{|c|}{ Welcome... } \\
\hline$?$ & Learn Adobe Acrobat Reader DC... & \\
\hline & About Adobe Acrobat Reader DC... & \\
\hline & About Adobe Plug-Ins... & \\
\hline & Generate System Report... & \\
\hline & Rẹpair Installation & \\
\hline & Check for $\underline{\text { Updates... }}$ & \\
\hline
\end{tabular}




\section{Author Query Form}

\section{Journal: Permafrost and Periglacial Processes}

\section{Article: ppp_1979}

Dear Author,

During the copyediting of your paper, the following queries arose. Please respond to these by annotating your proofs with the necessary changes/additions.

- If you intend to annotate your proof electronically, please refer to the E-annotation guidelines.

- If you intend to annotate your proof by means of hard-copy mark-up, please use the standard proofing marks. If manually writing corrections on your proof and returning it by fax, do not write too close to the edge of the paper. Please remember that illegible mark-ups may delay publication.

Whether you opt for hard-copy or electronic annotation of your proofs, we recommend that you provide additional clarification of answers to queries by entering your answers on the query sheet, in addition to the text mark-up.

\begin{tabular}{|c|c|c|}
\hline Query No. & Query & Remark \\
\hline Q1 & $\begin{array}{l}\text { AUTHOR: Please confirm that forenames/given names (blue) and surnames/family } \\
\text { names (vermilion) have been identified correctly. }\end{array}$ & \\
\hline Q2 & AUTHOR: Please verify that the linked ORCID identifiers are correct for each author. & \\
\hline Q3 & $\begin{array}{l}\text { AUTHOR: "Saint Petersburg State University, Russian Science Foundation, Russian } \\
\text { Foundation for Basic Research, Deutsche Forschungsgemeinschaft, } \\
\text { Bundesministerium für Bildung und Forschung" was identified as funder in the } \\
\text { supplied metadata, however, this funder was not mentioned in the acknowledgments } \\
\text { or funding information section. Please insert the appropriate text for this funder, or } \\
\text { confirm that this is to be deleted from the funders list. }\end{array}$ & \\
\hline Q4 & AUTHOR: should this be 'Lateglacial'? & \\
\hline Q5 & AUTHOR: '200-km scale' Please confirm that this is correct. & \\
\hline Q6 & $\begin{array}{l}\text { AUTHOR: 'overlying Last Glacial Maximum alluvial' Please confirm that this is } \\
\text { correct. }\end{array}$ & \\
\hline Q7 & $\begin{array}{l}\text { AUTHOR: If there are } 6 \text { authors for reference } 2 \text {, please supply all of their names. If } \\
\text { there are } 7 \text { or more authors, please supply the first } 3 \text { authors' names then et al. }\end{array}$ & \\
\hline Q8 & $\begin{array}{l}\text { AUTHOR: If there are } 6 \text { authors for reference } 3 \text {, please supply all of their names. If } \\
\text { there are } 7 \text { or more authors, please supply the first } 3 \text { authors' names then et al. }\end{array}$ & \\
\hline Q9 & $\begin{array}{l}\text { AUTHOR: If there are } 6 \text { authors for reference } 7 \text {, please supply all of their names. If } \\
\text { there are } 7 \text { or more authors, please supply the first } 3 \text { authors' names then et al. }\end{array}$ & \\
\hline Q10 & $\begin{array}{l}\text { AUTHOR: If there are } 6 \text { authors for reference } 8 \text {, please supply all of their names. If } \\
\text { there are } 7 \text { or more authors, please supply the first } 3 \text { authors' names then et al. }\end{array}$ & \\
\hline Q11 & $\begin{array}{l}\text { AUTHOR: If there are } 6 \text { authors for reference } 12 \text {, please supply all of their names. If } \\
\text { there are } 7 \text { or more authors, please supply the first } 3 \text { authors' names then et al. }\end{array}$ & \\
\hline Q12 & $\begin{array}{l}\text { AUTHOR: If there are } 6 \text { authors for reference } 14 \text {, please supply all of their names. If } \\
\text { there are } 7 \text { or more authors, please supply the first } 3 \text { authors' names then et al. }\end{array}$ & \\
\hline Q13 & $\begin{array}{l}\text { AUTHOR: If there are } 6 \text { authors for reference } 15 \text {, please supply all of their names. If } \\
\text { there are } 7 \text { or more authors, please supply the first } 3 \text { authors' names then et al. }\end{array}$ & \\
\hline Q14 & $\begin{array}{l}\text { AUTHOR: If there are } 6 \text { authors for reference } 16 \text {, please supply all of their names. If } \\
\text { there are } 7 \text { or more authors, please supply the first } 3 \text { authors' names then et al. }\end{array}$ & \\
\hline
\end{tabular}




\begin{tabular}{|c|c|c|}
\hline Query No. & Query & Remark \\
\hline Q15 & $\begin{array}{l}\text { AUTHOR: If there are } 6 \text { authors for reference } 29 \text {, please supply all of their names. If } \\
\text { there are } 7 \text { or more authors, please supply the first } 3 \text { authors' names then et al. }\end{array}$ & \\
\hline Q16 & $\begin{array}{l}\text { AUTHOR: If there are } 6 \text { authors for reference } 30 \text {, please supply all of their names. If } \\
\text { there are } 7 \text { or more authors, please supply the first } 3 \text { authors' names then et al. }\end{array}$ & \\
\hline Q17 & $\begin{array}{l}\text { AUTHOR: If there are } 6 \text { authors for reference } 32 \text {, please supply all of their names. If } \\
\text { there are } 7 \text { or more authors, please supply the first } 3 \text { authors' names then et al. }\end{array}$ & \\
\hline Q18 & $\begin{array}{l}\text { AUTHOR: If there are } 6 \text { authors for reference } 40 \text {, please supply all of their names. If } \\
\text { there are } 7 \text { or more authors, please supply the first } 3 \text { authors' names then et al. }\end{array}$ & \\
\hline Q19 & $\begin{array}{l}\text { AUTHOR: If there are } 6 \text { authors for reference } 41 \text {, please supply all of their names. If } \\
\text { there are } 7 \text { or more authors, please supply the first } 3 \text { authors' names then et al. }\end{array}$ & \\
\hline Q20 & $\begin{array}{l}\text { AUTHOR: If there are } 6 \text { authors for reference } 57 \text {, please supply all of their names. If } \\
\text { there are } 7 \text { or more authors, please supply the first } 3 \text { authors' names then et al. }\end{array}$ & \\
\hline Q21 & $\begin{array}{l}\text { AUTHOR: If there are } 6 \text { authors for reference } 59 \text {, please supply all of their names. If } \\
\text { there are } 7 \text { or more authors, please supply the first } 3 \text { authors' names then et al. }\end{array}$ & \\
\hline Q22 & $\begin{array}{l}\text { AUTHOR: If there are } 6 \text { authors for reference } 67 \text {, please supply all of their names. If } \\
\text { there are } 7 \text { or more authors, please supply the first } 3 \text { authors' names then et al. }\end{array}$ & \\
\hline Q23 & $\begin{array}{l}\text { AUTHOR: If there are } 6 \text { authors for reference } 72 \text {, please supply all of their names. If } \\
\text { there are } 7 \text { or more authors, please supply the first } 3 \text { authors' names then et al. }\end{array}$ & \\
\hline Q24 & $\begin{array}{l}\text { AUTHOR: If there are } 6 \text { authors for reference } 74 \text {, please supply all of their names. If } \\
\text { there are } 7 \text { or more authors, please supply the first } 3 \text { authors' names then et al. }\end{array}$ & \\
\hline
\end{tabular}

Please confirm that the funding sponsor list below was correctly extracted from your article: that it includes all funders and that the text has been matched to the correct FundRef Registry organization names. If a name was not found in the FundRef registry, it may not be the canonical name form, it may be a program name rather than an organization name, or it may be an organization not yet included in FundRef Registry. If you know of another name form or a parent organization name for a "not found" item on this list below, please share that information.

\begin{tabular}{|l|l|}
\hline FundRef Name & FundRef Organization Name \\
\hline Bundesministerium für Bildung und Forschung & Bundesministerium für Bildung und Forschung \\
\hline Deutsche Forschungsgemeinschaft & Deutsche Forschungsgemeinschaft \\
\hline Russian Foundation for Basic Research & Russian Foundation for Basic Research \\
\hline Russian Science Foundation & Russian Science Foundation \\
\hline Saint Petersburg State University & Saint Petersburg State University \\
\hline
\end{tabular}




\section{Holocene thermokarst and pingo development in the Kolyma Lowland (NE Siberia)}

${ }^{1}$ Alfred Wegener Institute Helmholtz Centre for Polar and Marine Research, Potsdam, Germany

${ }^{2}$ Kazan Federal University, Kazan, Russian Federation

${ }^{3}$ University of Potsdam, Institute of Earth and Environmental Science, Potsdam, Germany

${ }^{4}$ Faculty of Soil Science, Lomonosov Moscow State University, Moscow, Russian Federation ${ }^{5}$ Universidad Autónoma de México, Instituto de Geología, Posgrado en Ciencias de la Tierra, Ciudad de México, Mexico

${ }^{6}$ St. Petersburg State University, Institute of Earth Sciences, St Petersburg, Russian Federation

${ }^{7}$ Herzen State Pedagogical University, Institute of Geography, St Petersburg, Russian Federation

${ }^{8}$ Karelian Research Centre, Russian Academy of Sciences, Northern Water Problems Institute, Petrozavodsk, Russian Federation

${ }^{9}$ Department of Geography, University of Sussex, Brighton, UK

Correspondence

Sebastian Wetterich, Alfred Wegener Institute Helmholtz Centre for Polar and Marine Research, Telegrafenberg A45, Potsdam, 14473, Germany.

Email: sebastian.wetterich@awi.de

\section{Funding information}

Bundesministerium für Bildung und

Forschung, Grant/Award

Number: 01DJ14003; Deutsche

Forschungsgemeinschaft, Grant/Award

Number: HE 3622/16-1; Russian Foundation

for Basic Research, Grant/Award

Number: 11-04-91332-NNIO-a; Russian

Science Foundation, Grant/Award

Number: 16-17-10118; Saint Petersburg State University, Grant/Award

Number: 18.40.68.2017

\begin{abstract}
Ground ice and sedimentary records of a pingo exposure reveal insights into Holocene permafrost, landscape and climate dynamics. Early to mid-Holocene thermokarst lake deposits contain rich floral and faunal paleoassemblages, which indicate lake shrinkage and decreasing summer temperatures (chironomid-based $T_{\text {July }}$ ) from 10.5 to $3.5 \mathrm{cal} \mathrm{kyr} \mathrm{BP}$ with the warmest period between 10.5 and $8 \mathrm{cal}$ kyr BP. Talik refreezing and pingo growth started about $3.5 \mathrm{cal}$ kyr BP after disappearance of the lake. The isotopic composition of the pingo ice $\left(\delta^{18} \mathrm{O}-17.1 \pm 0.6 \%\right.$, $\delta \mathrm{D}$ $-144.5 \pm 3.4 \%$ o, slope 5.85 , deuterium excess $-7.7 \pm 1.5 \%$ o) point to the initial stage of closed-system freezing captured in the record. A differing isotopic composition within the massive ice body was found $\left(\delta^{18} \mathrm{O}-21.3 \pm 1.4 \%\right.$ o, $\delta \mathrm{D}-165 \pm 11.5 \%$, slope 8.13 , deuterium excess $4.9 \pm 3.2 \%$ o), probably related to the infill of dilation cracks by surface water with quasi-meteoric signature. Currently inactive syngenetic ice wedges formed in the thermokarst basin after lake drainage. The pingo preserves traces of permafrost response to climate variations in terms of ground-ice degradation (thermokarst) during the early and mid-Holocene, and aggradation (wedge-ice and pingo-ice growth) during the late Holocene.
\end{abstract}

\section{KEYWORDS}

bioindicators, cryolithology, hydrochemistry, Khalerchinskaya tundra, stable water isotopes 


\section{I INTRODUCTION}

The interplay of permafrost aggradation and degradation shapes modern landscapes as it shaped past ones in vast areas of subarctic and arctic lowlands. Thus, traces of periglacial landforms preserved in permafrost deposits may contain records of past climate and landscape development. Besides climate control, also topography, hydrology, subsurface properties, vegetation and snow cover mediate

permafrost conditions. ${ }^{1}$ Since the lateglacial warming and especially during the early Holocene thermal optimum extensive thaw took place in regions of continuous permafrost distribution. ${ }^{2}$ Thermokarst, induced by active-layer deepening that triggered ground-ice melt and subsidence formed basins and valleys over hundreds of years. The climate-controlled response of ice-rich continuous permafrost to warming is addressed in current research. ${ }^{3}$ Besides permafrost degradation during past and ongoing warming, concurrent permafrost aggradation and ground-ice formation is common and triggered by localized controls on the landscape scale. ${ }^{1}$ Prominent landforms related to ground-ice formation are hydrostatic (closed-system) pingos, which might form in drained thermokarst-lake basins. ${ }^{4}$ Due to the growth of the ice core the terrain surface and above-lying deposits dome up and have a characteristic elliptical to circular planar shape reaching heights of up to several tens of meters. ${ }^{5}$

Pingos are common features in circum-arctic lowlands with continuous permafrost, and are rather well studied in the North American Arctic in terms of formation, ${ }^{6}$ structure $^{7}$ and distribution. ${ }^{8}$ Pingo growth and decay rates, age, and past distribution have been used for the reconstruction of past periglacial landscape conditions.9-12 Pingo inventories were furthermore used in paleo-environmental reconstructions in the Mackenzie Delta in Canada, ${ }^{13}$ on Seward Peninsula in Alaska ${ }^{14,15}$ and in Central Yakutia. ${ }^{16}$ A modern spatial database shows more than 6000 pingos in a $3.5 \times 10^{6} \mathrm{~km}^{2}$ region in the Eurasian Subarctic and Arctic, and links the pingo distribution to permafrost and landscape characteristics, to surface geology and morphology, and to hydrology and climate. ${ }^{17}$

In the course of Russian-German fieldwork in 2012 in the Kolyma Lowland, ${ }^{18}$ different features of periglacial landscapes were studied, F1 including a pingo exposure near Pokhodsk (Figure 1, 69 $2^{\prime} 18.096^{\prime \prime} \mathrm{N}$, $\left.161^{\circ} 0^{\prime} 23.112^{\prime \prime} \mathrm{E}\right)$. The ice core of the pingo locally named "Shirokovsky Kholm" became exposed because in summer 2003 a fire burned overlying peaty soils (personal communication by Natalya Ivanovna Arbatskaya, Pokhodsk), which caused extensive melting of the massive ice, thaw slumping and slope erosion in its northern part (Figure 1d). This man-made impact caused the onset of rapid pingo destruction, which now provides access to otherwise buried pingo ice, deposits and internal structures. To characterize the pingo and to determine its formation, sampling of the exposed ice, enclosing frozen deposits and overlying soils was undertaken.

The pingo exposure and the surrounding modern thermokarst lake were studied and sampled to obtain representative information on both the thermokarst features and the pingos, which characterize large areas of the Kolyma Lowland. The study aims (1) to determine the timing of thermokarst lake and pingo development by applying radiocarbon dating, (2) to characterize paleo-ecological and paleo-climatic dynamics by analyzing micropaleontological proxy data to the lacustrine thermokarst deposits, and (3) to characterize the permafrost and ground-ice inventory by applying cryolithological, hydrochemical and stable isotope methods. Overall, the study aims to reconstruct Holocene landscape dynamics of thermokarst and pingo development in the Kolyma Lowland.

\section{2 | MATERIAL AND METHODS}

\section{1 | Study region}

The study site is situated in the Kolyma Lowland at the boundary between the Khalerchinskaya Tundra and the Kolyma Delta (Figure 1 b). The Kolyma Delta extends mainly at 2-4 m above sea level (a.s.l.) at the mouth of the Kolyma River into the East Siberian Sea while the Khalerchinskaya Tundra, southwest of the delta, reaches up to 15-25 m a.s.l. ${ }^{19}$ Both regions are characterized by widespread thermokarst. ${ }^{19}$ The Kolyma River divides into three major channels named Kolymskaya (Kamennaya), Pokhodskaya and Chukoch'ya, and numerous smaller channels. ${ }^{20}$ The study region is mostly underlain by Neogene sand, silt, clay, peat and gravel. ${ }^{21}$ The Quaternary map of the region shows late Holocene marine-alluvial deposits in the Kolyma Delta, early Holocene marine-alluvial deposits in the Pokhodsk area, and late Holocene limnic-palustrine deposits in the Khalerchinskaya Tundra. ${ }^{22}$

The subarctic continental climate of the Kolyma Lowland is characterized by high annual temperature amplitudes and low precipitation $\left(T_{\text {July }}+7.5^{\circ} \mathrm{C}, T_{\text {January }}-31.7^{\circ} \mathrm{C}^{23} ; P_{\text {Annual }} 290 \mathrm{~mm}\right.$, Cherskiy, WMO station no. 25123). The region belongs to the continuous permafrost zone with ground temperatures of -7 to $-5^{\circ} \mathrm{C}$ and a permafrost thickness reaching $100-300 \mathrm{~m}^{24}$

The main features of the surface morphology relate to annual freeze and thaw processes. Ice-wedge polygons at all development stages (low- and high-center polygons, coalescent polygon ponds) as well as thermokarst lakes shape wide areas of the Kolyma floodplain and river terraces. Microrelief features such as elevated rims of low-center polygons and varying active-layer depths cause highly diverse soil-moisture distribution, which is reflected in the vegetation cover of polygon tundra in the study area. ${ }^{25}$ Boreal aquatic plants such as Menyanthes trifoliata, Comarum palustre and several Utricularia species are common in wet areas while the occurrence of several boreal shrub and dwarf-shrub species including Duschekia fruticosa, Chamaedaphne calyculata, Vaccinium spp. and even scattered Larix stands indicate drier sites, ${ }^{26}$ and reflect the proximity to the northern tree line. According to the Circumpolar Arctic Vegetation Map, ${ }^{27}$ the study area is described as sedge, moss low-shrub wetland (W3) and low-shrub tundra (S2). Salix shrubs, mosses and grasses dominate the vegetation of the study site while in windprotected areas Betula nana occurs. On the southern part of the pingo top, a bowl-like depression is vegetated by Sphagnum sp., Rubus chamaemous, Vaccinium vitis-idaea, Veratrum lobelianum, Ledum decumbens and Chamerion angustifolium. The soil cover is composed of Typic Historthels, Typic Sapristels, Typic Hemistels, Typic and Sphagnic Fibristels, and Typic Psammorthels reflecting different contents and degrees of decomposition of organic matter (OM) within 
the active layer. The thaw depth reached a maximum of $40 \mathrm{~cm}$ on the surface of the pingo (August 20, 2012).

The studied pingo remnant still occupies about three-quarters of its former extent (Figure 1d). The pingo remnant borders a thermokarst lake, which is paludified south-west of the pingo (Figure $1 \mathrm{c}$, d). The largest extension of the pingo remnant is about $160 \mathrm{~m}$ and its height reaches up $17.6 \mathrm{~m}$ a.s.l. (Figure 1e); this is equivalent to about $12.8 \mathrm{~m}$ above lake level (a.I.I.).
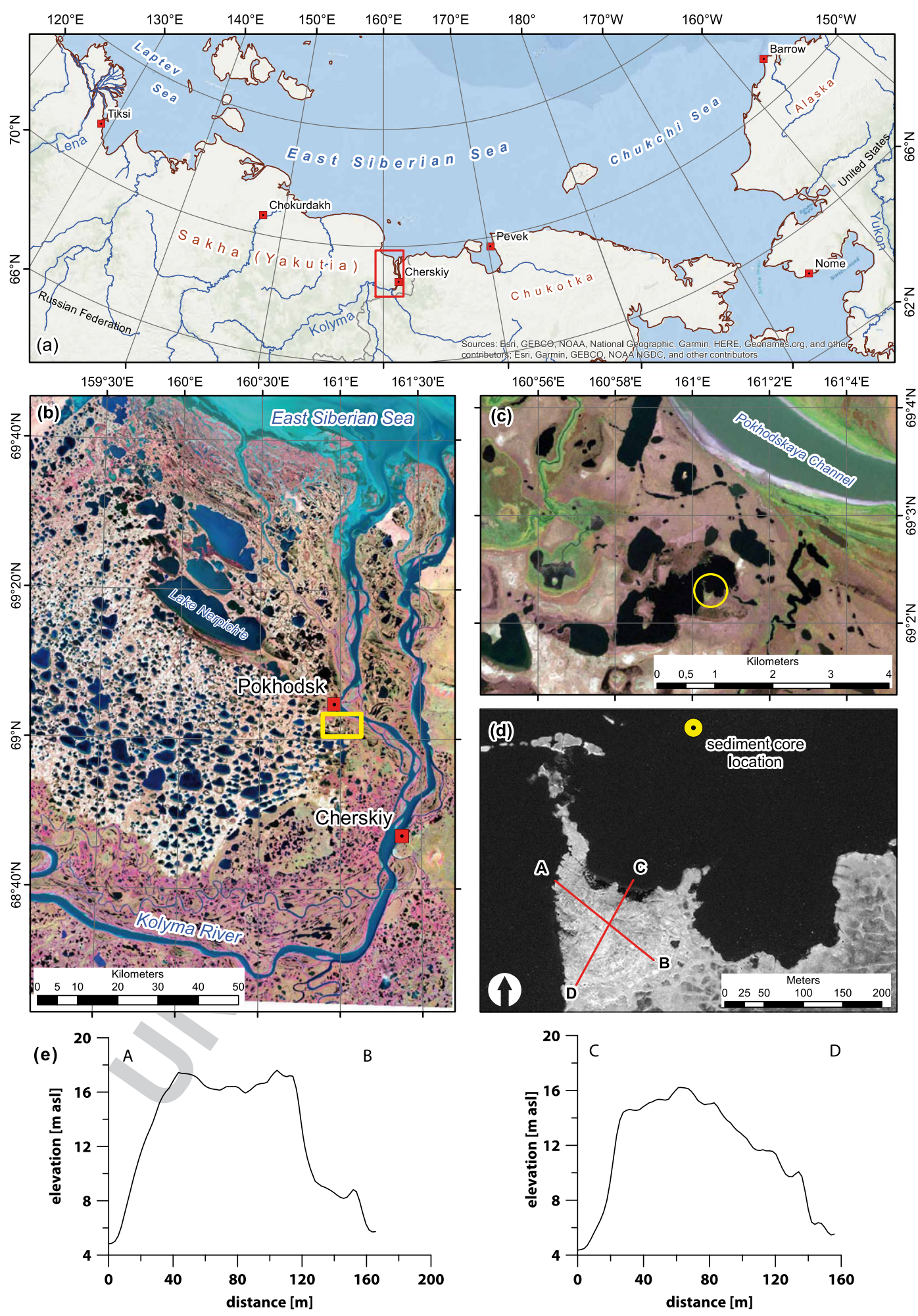

FIGURE 1 Location of the study area (a) in the eastern Siberian Arctic, (b) on a map of the Khalerchinskaya Tundra in the Kolyma Lowland (background false color infrared image of Sentinel-2, August 31, 2017), (c) in a close up view of the pingo-hosting thermokarst lake basin (true color representation) and (d) on a WorldView-1 satellite image (June 28, 2009) showing erosional pingo margins along lake shore and elevation profile locations given in (e) based on ArcticDEM digital elevation model data at 2-m resolution, created from a WorldView-2 stereo pair acquired on April 12, 2013 [Colour figure can be viewed at wileyonlinelibrary.com] 


\section{2 | Fieldwork}

Ice and sediment samples were taken between August 19 and 22, 2012 by axe and hammer in the north-facing part of the pingo in different steep exposures of pingo-core ice and frozen sediment F3 F2 (Figures 2 and 3, Supporting Information Figure S1). Three profiles named 12P-1908-A, 12P-2008-A and 12P-2208-A were sampled in horizontal and/or vertical directions (Figures 3 and S1). Additionally, a lake sediment short core named 80-1 (taken with a UWITEC gravity corer) and water samples from the modern lake surrounding the pingo were taken at different depths. Still in the field, $\mathrm{pH}$ and electrical conductivity (EC) measurements of melted ice and water samples were performed using a WTW340i pocket meter equipped with a Tetracon 925 conductivity cell for EC (reference temperature: $25^{\circ} \mathrm{C}$ ) and Sentix 43-1 electrode for $\mathrm{pH}$ measurements.

\section{3 | Sediment and intrasedimental ice studies}

Cryostructures of frozen soils formed by pore ice and small lenses of segregated ice (hereafter referred to as "intrasedimental ice") were described ${ }^{28}$ and the gravimetric ice content was measured as a ratio of the weight difference between frozen and dried bulk sediment samples to the weight of dry samples and is expressed as a weight percentage (wt\%). The grain-size distribution and OM properties (total nitrogen [TN], total organic carbon [TOC] and $\delta^{13} \mathrm{C}$ of TOC) in sedimentary samples were measured; methods are described in detail by Wetterich et al. ${ }^{29}$ The ratio of TOC and TN is referred to as $\mathrm{C} / \mathrm{N}$.

\section{4 | Radiocarbon dating}

A total of 13 radiocarbon dates from the exposed sediment and two dates from a short core (core code 80-1) in the modern lake were obtained by AMS at Poznan Radiocarbon Laboratory (Poland). Radiocarbon dates were obtained from unidentified moss, peat and plant detritus. Dates are reported as ages in calibrated radiocarbon years before present (cal yr BP) by applying the calibration data set IntCal $13^{30}$ (Table 1) as derived from the age-depth modeling routine with the R $\mathbf{T} 176$ BACON (Bayesian accumulation histories) software. ${ }^{31}$ Median values were taken to calculate the ages of events and zonation.

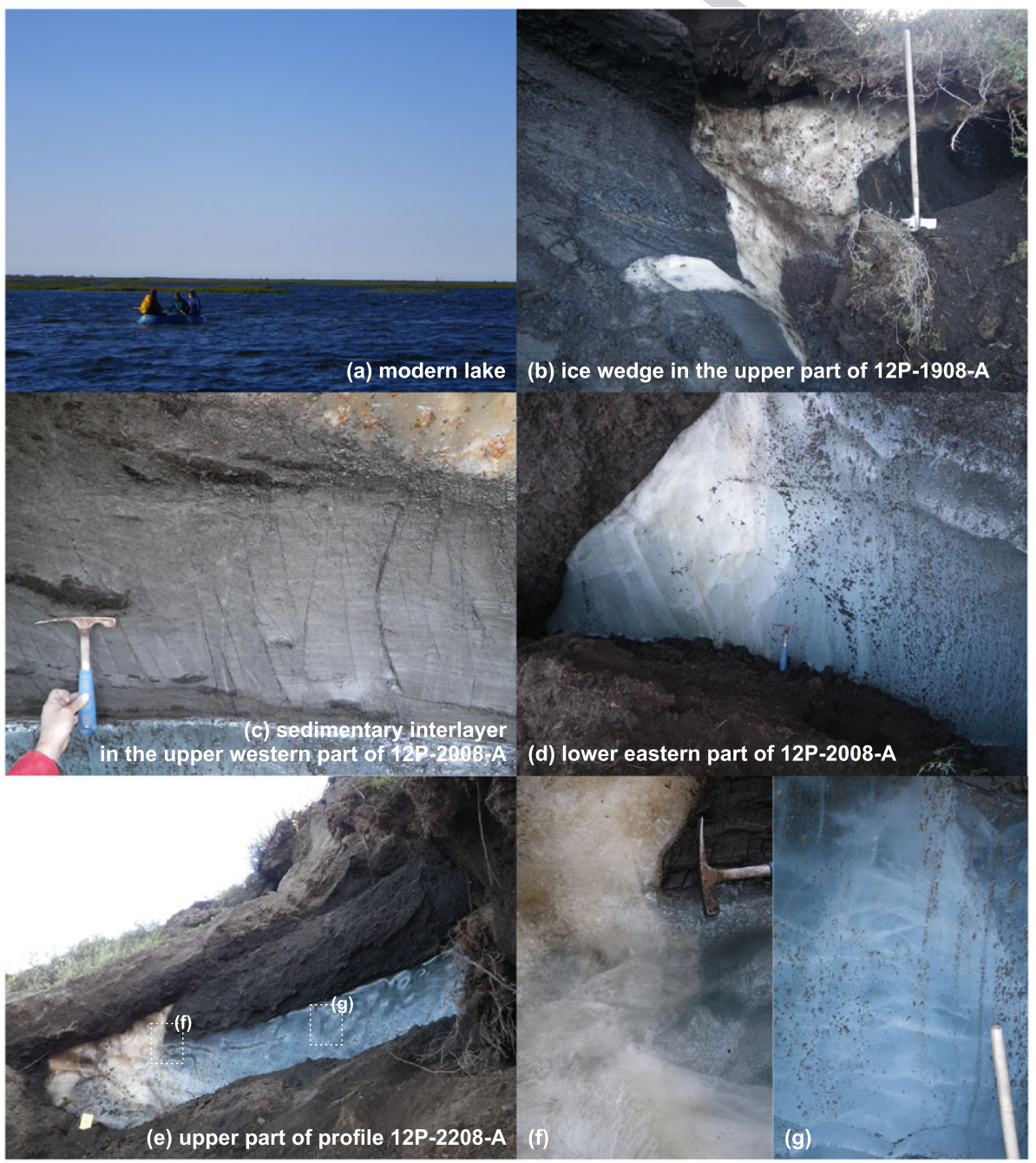

FIGURE 2 Photographs of the pingo "Shirokovsky Kholm" showing (a) the modern lake surrounding the pingo, (b) a syngenetic ice wedge on top of profile 12P-1908-A, (c) a bedded sedimentary interlayer of profile 12P-2008-A (sample no. -03, to -05 in Figure S1b) with vertical ice veins and peaty inclusions, (d) bubble-rich clear ice of profile 12P-2008-A (sample no. -19 in Figure S1b), (e) the upper part of profile 12P-2208-A with close-ups of the pingo ice shown in ( $\mathrm{f}$ ) whitish ice with small ice crystals (up to $5 \times 10 \mathrm{~mm}$ ) and small bubbles (<1 mm in diameter) nonregularly distributed (sample no. -20 , to -23 in Figure S1c) and (g) clear ice with larger ice crystals (up to $20 \times 30 \mathrm{~mm}$ ) and larger bubbles ( $1 \mathrm{~mm}$ in diameter) in subvertical and horizontal layers (sample no. -19 in Figure S1c) [Colour figure can be viewed at wileyonlinelibrary.com] 
E

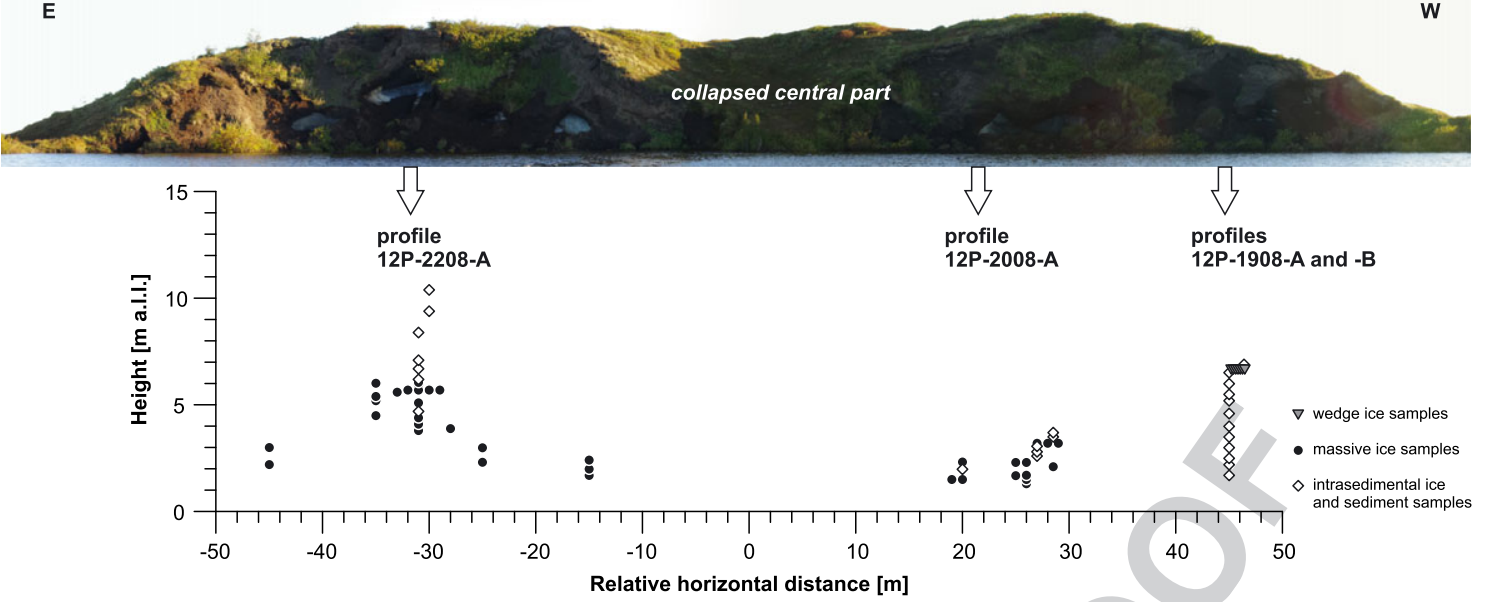

FIGURE 3 Overview of the sampled outcrop at the pingo exposure "Shirokovsky Kholm." Note that the photograph is not to scale. Details of the sampled profiles are given in Figure S1 [Colour figure can be viewed at wileyonlinelibrary.com]

\subsection{Stable water isotopes and hydrochemistry of ground ice}

The stable-isotope hydrogen $(\delta \mathrm{D})$ and oxygen $\left(\delta^{18} \mathrm{O}\right)$ and the ion compositions of ground ice were analyzed; methods are described in detail by Fritz et al. ${ }^{32}$ Internal $1 \sigma$ errors are less than $0.8 \%$ for $\delta D$ and $0.1 \% \circ \delta^{18} \mathrm{O} .{ }^{33}$ The deuterium excess (d excess) ${ }^{34}$ is calculated as $\mathrm{d}=\delta \mathrm{D}-8 \times \delta^{18} \mathrm{O}$.

To classify the analytical data of the 35 massive ice samples (EC, $\mathrm{pH}$, anions, cations, stable isotopes; Table S1) we used cluster analysis. lons with values below the detection level in more than $50 \%$ of the ice samples were excluded from the analysis. Samples were normalized to account for the different characteristics of the analytical data. We chose agglomerative hierarchical clustering as the sample size is relatively small and no starting points or number of clusters need to be supplied. To assess the significance of possible clusters, we used the pvclust R package ${ }^{35}$ for hierarchical clustering with $P$ values, which supplies probabilities for each edge in the cluster dendrogram. Distances between samples were determined using Euclidean distances; the clustering method used was "complete" (maximum distance). The approximately unbiased $P$ values (AU) provided by pvclust are based on multiscale bootstrap resampling (100 000 times) and were used for separation into a reasonable number of clusters.

\section{6 | Micropaleontology}

Profile 12P-1908-A was studied for its micropaleontological inventory of pollen, nonpollen palynomorphs (NPPs), testaceans, diatoms and chironomids. Samples for pollen and NPP analysis were prepared from

TABLE $1 \mathrm{AMS}^{14} \mathrm{C}$ dating results. All samples are calibrated using Calib Rev $7.0 .2,{ }^{30}$ calibration data set intcal13.14c as derived from the agedepth modeling routine with $\mathrm{R}$ BACON

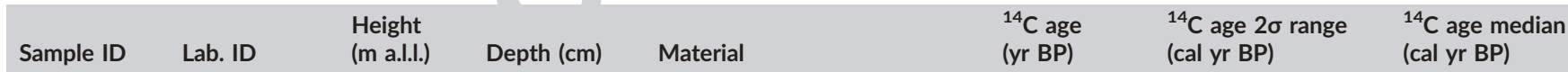

Short core 80-1

$\begin{array}{ll}-13 & \text { Poz-55452 } \\ -22 & \text { Poz-55453 }\end{array}$

Profile 12P-1908-A

$\begin{array}{rll}-09 & \text { Poz-50918 } & 6.5 \\ -12 & \text { Poz-50919 } & 5.2 \\ -14 & \text { Poz-50920 } & 4 \\ -17 & \text { Poz-50921 } & 2.5 \\ -19 & \text { Poz-50923 } & 1.7\end{array}$

Profile 12P-2008-A

$\begin{array}{lll}-01 & \text { Poz-50915 } & 3.7 \\ -04 & \text { Poz-50916 } & 2.8 \\ -17 & \text { Poz-50917 } & 2\end{array}$

$\begin{array}{lll}-17 & \text { Poz-50917 } 2\end{array}$

Profile 12P-2208-A

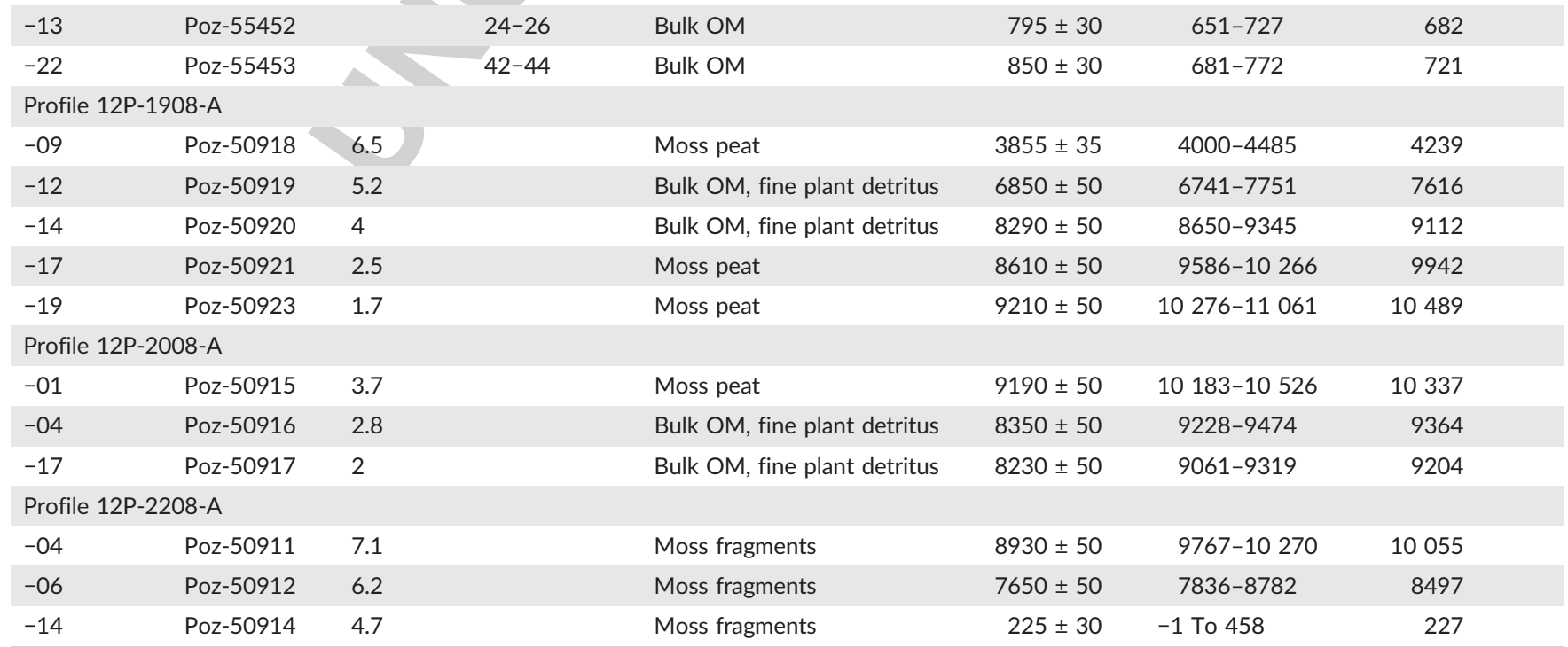


0.44 to $4.0 \mathrm{~g}$ of sediment and processed following standard procedures. ${ }^{36}$ In total, 300 pollen grains per sample were counted and identified. ${ }^{37,38}$ For testacean (testate amoebae) analysis, samples were suspended in purified water and wet-sieved (500- $\mu \mathrm{m}$ screen). Sphagnobiontic, soil-eurybiontic and hydrobiontic ecological groups are distinguished based on habitat preferences. ${ }^{39,40}$ The diatom analysis followed standard techniques. ${ }^{41}$ Up to 300 valves per sample were counted and identified. ${ }^{42,43}$ Biogeographical and ecological characteristics of the diatom taxa are based on Barinova et al. ${ }^{44}$ The coefficient of floristic similarity of taxa composition was calculated according to Sorensen and Czekanovsky, ${ }^{45}$ and expressed in percentages. The reconstruction of $\mathrm{pH}$ is based on the European Diatom Database. ${ }^{46}$ The chironomid analysis followed standard techniques ${ }^{47}$ and taxa identification followed Wiederholm ${ }^{48}$ and Brooks et al. ${ }^{49}$ Chironomid ecology and mean air temperature values of the warmest month $\left(T_{\text {July }}\right)$ were taken from Brooks et al. ${ }^{49}$ and Nazarova et al. ${ }^{50,51}$ Effective occurrence numbers of chironomid taxa were estimated using the N2 index. ${ }^{52}$ Air $T_{\text {July }}$ values were inferred using a chironomid-based temperature inference model. ${ }^{51}$

\section{3 | RESULTS}

\section{1 | Modern lake environment and subrecent diatoms}

The modern thermokarst lake surrounding the pingo has $\mathrm{pH}$ values between 6.4 and 6.8 and EC of $52 \mu \mathrm{S} / \mathrm{cm}$ in water samples taken between 0 and $2.4 \mathrm{~m}$ depth. The $46-\mathrm{cm}$-long lacustrine sediment core is composed of gray and brown silts and sands with occasional plant detritus. The diatom record of the upper $24 \mathrm{~cm}$ of the core differentiates into four zones, which are described and shown in detail in Figure S2. The lowermost zone A (24-22 cm depth) contains 12 taxa with Staurosirella pinnata, Eunotia incisa and $E$ praerupta dominating. Acidophilic and cold-water species prevail. Zone B (22-14 cm depth) with 53 taxa is much more diverse. Phytophilic species of the genus Encyonema are notable. The increase of $S$. pinnata and $E$. incisa as well as increasing diversity and the new appearance of dominant species such as Fragilaria construens, Achnanthidium minutissimum and Cocconeis placentula indicate increasing temperatures, expansion of the growing season and increase in siliciclastic sediment supply in the catchment. ${ }^{44}$ A total of 62 species mainly from benthic and alkaliphilic groups were found in zone C (14-6 cm depth). Decreasing water level, rising temperature and ion content are detected. The uppermost zone $\mathrm{D}$ (6-0 $\mathrm{cm}$ depth) reflects the modern lake conditions, where 62 species are present, of which benthic and alkaliphilic species predominate. $S$. pinnata has highest share of the entire short core record.

\section{2 | Geochronology}

The age information from sediment samples derives from 13 radiocarbon dates from plant material of the short core of the modern lake sediment and from three pingo profiles (Table 1). Two radiocarbon dates from 24 to 26 and $42-44 \mathrm{~cm}$ core depth of the core $80-1$ reveal ages of 682 and $721 \mathrm{cal}$ yr BP, respectively. The modeled age-height relationship of profile $12 \mathrm{P}-1908-\mathrm{A}$ based on five dates is shown in
Figure S3 and spans from about 10.5 to 3.5 cal kyr BP. Early Holocene radiocarbon dates of sediments enclosing the pingo ice from profiles 12P-2008-A and 12P-2208-A range between 10.3 and 8.5 cal kyr BP.

\section{3 | Cryostratigraphy}

\subsection{1 | Profile 12P-1908-A}

Profile $12 \mathrm{P}-1908-\mathrm{A}$ is located at the western edge of the study site (Figure 3). The 12P-1908-A profile comprises a 6-m-thick sequence of frozen peat and ice layers, fine-grained lacustrine sediments and an ice wedge on top (Figures 2b, S1a). It accumulated between about 10.5 and 3.5 cal kyr BP (Figures 4, S3). Three units are distinguished F4 71 based on cryolithological properties. The lowermost unit $A$ between 1.7 and $3.2 \mathrm{~m}$ a.l.I. exhibits light brown moss peat with nonparallel wavy lenticular cryostructures (1-2 cm thick), and encloses two segregated ice layers $(20-30 \mathrm{~cm}$ thick) at 2.2 and $3 \mathrm{~m}$ a.l.I. with air bubbles 1-2 $\mathrm{mm}$ in diameter. Unit B between 3.2 and $5 \mathrm{~m}$ a.I.I. is built of bedded gray silt (single lamina up to $10 \mathrm{~mm}$ thick) and grey-brown plant detritus (single lamina up to $5 \mathrm{~mm}$ thick). At $4.6 \mathrm{~m}$ a.l.l. a light brown moss peat occurs. The cryostructures are nonparallel wavy lenticular and irregular reticulate (ice lenses up to $1 \mathrm{~mm}$ thick and up to $20 \mathrm{~mm}$ long). The uppermost unit $\mathrm{C}$ between 5 and $6.5 \mathrm{~m}$ a.l. I. exhibits grey-brown silty fine sands with peaty inclusions, and irregular reticulate cryostructures and occasional lenses of clear ice up to $1 \mathrm{~cm}$ thick with air bubbles up to $1 \mathrm{~mm}$ in diameter. The ice wedge of unit $C$ is $1.8 \mathrm{~m}$ in visible width and $1.2 \mathrm{~m}$ in visible vertical extent and exhibits shoulders typical of syngenetic growth (Figure $2 b$ ). The ice wedge is not related to the modern surface (ie, no evidence for recent rejuvenation and polygon pattern on the slope surface) and is therefore assumed to be inactive. The wedge ice contains numerous vertically elongated and rounded air bubbles of up to $1 \mathrm{~mm}$ in diameter. Its isotopic composition ( $n=7$ ) is on average $-26.6 \pm 0.7 \%$ 。 for $\delta^{18} \mathrm{O},-202.7 \pm 6.0 \%$ o for $\delta \mathrm{D}$ and $10.0 \pm 0.7 \%$ o for $\mathrm{d}$ excess (Figure 5a, Table 2). The hydrochemical composition of the wedge $\mathbf{F 5} \mathrm{T2}$ ice was estimated in the central part (sample 12P-1908-A-04-IW; Table S1). The EC is rather low $(66 \mu \mathrm{S} / \mathrm{cm})$ and the $\mathrm{pH}$ is low (pH 5.7).

The grain size of profile 12P-1908-A shows bimodal and polymodal distributions (Figure S4). OM content varies in TOC from 6.3 to 37 wt\% and in TN from 0.5 to 2.5 wt\% (Figures 4, S5) with higher TOC and TN values and higher $\mathrm{C} / \mathrm{N}$ in peaty samples (Figure 4). The $\delta^{13} \mathrm{C}$ of TOC shows low variation with an average value of $-28.4 \%$.

The ice content varies from 56 to $100 \mathrm{wt} \%$. The EC of the intrasedimental ice is low at $40 \mu \mathrm{S} / \mathrm{cm}$ and the $\mathrm{pH}$ is slightly acidic (5.9). The isotope composition of intrasedimental ice with $\delta^{18} \mathrm{O}$ of $-17.9 \pm 0.7 \%$ o, $\delta \mathrm{D}$ of $-148.8 \pm 4.4 \%$ ond $d$ excess of $-5.8 \pm 1.3 \%$ 。 differs from those of the ice layers in unit $A$ of the profile: $-15.3 \pm 0.3 \%$ o for $\delta^{18} \mathrm{O},-133.7 \pm 2.6 \%$ o for $\delta \mathrm{D}$ and $-10.9 \pm 0 \%$ for $d$ excess (Figure 4, Table 2).

\subsection{2 | Profile 12P-2008-A}

The profile 12P-2008-A between about 1 and $3 \mathrm{~m}$ a.l.I. represents the massive ice of the pingo core, which has been sampled in different 
(a) profile 12P-1908-A

$\diamond \mathrm{TN} \quad \diamond \delta^{13} \mathrm{C} \quad$ Grain-size [wt\%] [\%] [vol\%] $\diamond$ Intrased. ice

סD [\%o]

$-200-150-100$

(b) profile 12P-2008-A

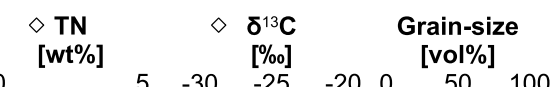
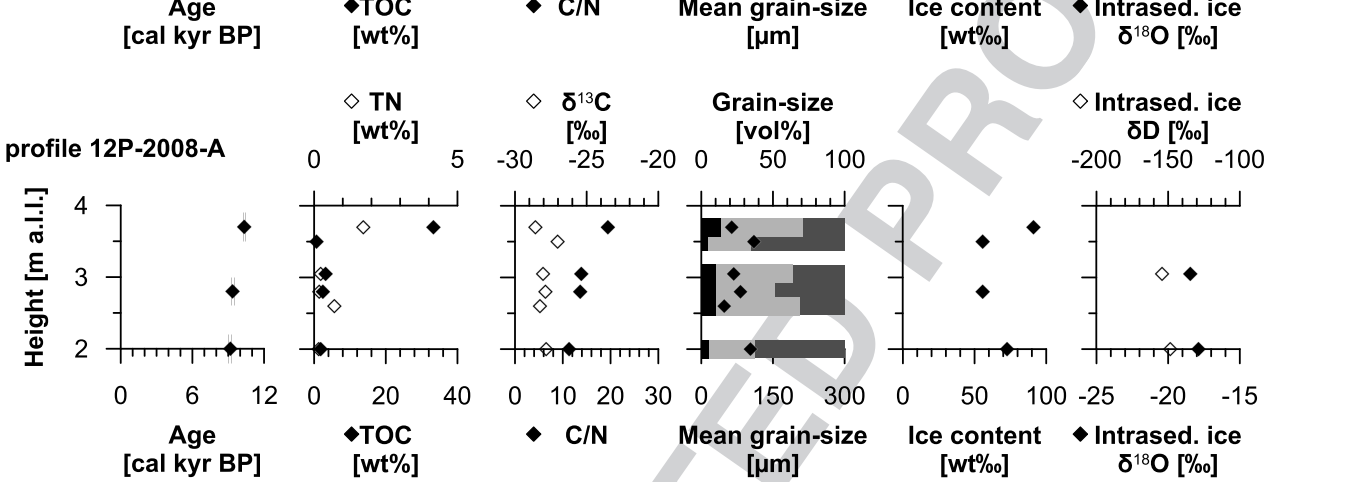

parts over a lateral distance of about $10 \mathrm{~m}$ (Figure 3). Approximate sampling positions are given in Figures 3 and S1b.

Samples of enclosing sediments have additionally been taken (Figure S1b) and radiocarbon-dated to early Holocene ages between 10.3 and 9.2 cal kyr BP (Figure 4, Table 1). These deposits include alternating beds of gray fine sand and brownish plant detritus with peat inclusions and subvertical ice veins (Figures 2c, S1b). The grainsize distribution is bimodal (Figure S4) and OM content is low with TOC values of $0.6-3.2$ wt\%, except for the uppermost sample of brown peat with TOC of $33.3 \mathrm{wt} \%$ (Figure 4). $\mathrm{C} / \mathrm{N}$ and $\delta^{13} \mathrm{C}$ of TOC signatures as well as ice content and stable water isotope composition are similar to those of unit B of profile 12P-1908-A.

The massive ice itself differs in color and air bubble content and distribution. Clear pingo ice with large crystals (up to $30 \times 50 \mathrm{~mm}$ ) but no bubbles occurs in places while most of the exposed pingo ice contains air bubbles (up to $2 \mathrm{~mm}$ in diameter) with vertical, horizontal and subvertical orientation (Figure $2 \mathrm{~d}$ ). Vertically oriented bubbles are often elongated. The stable water isotope composition of the 


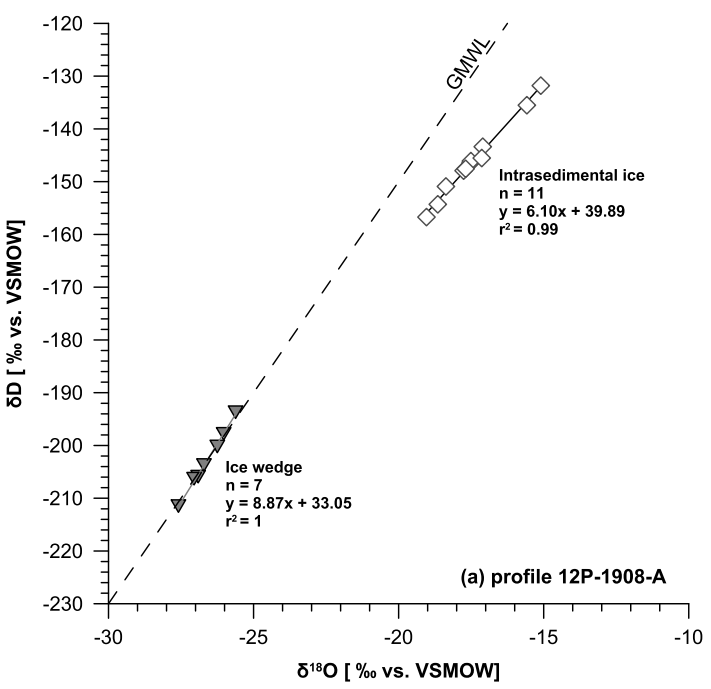

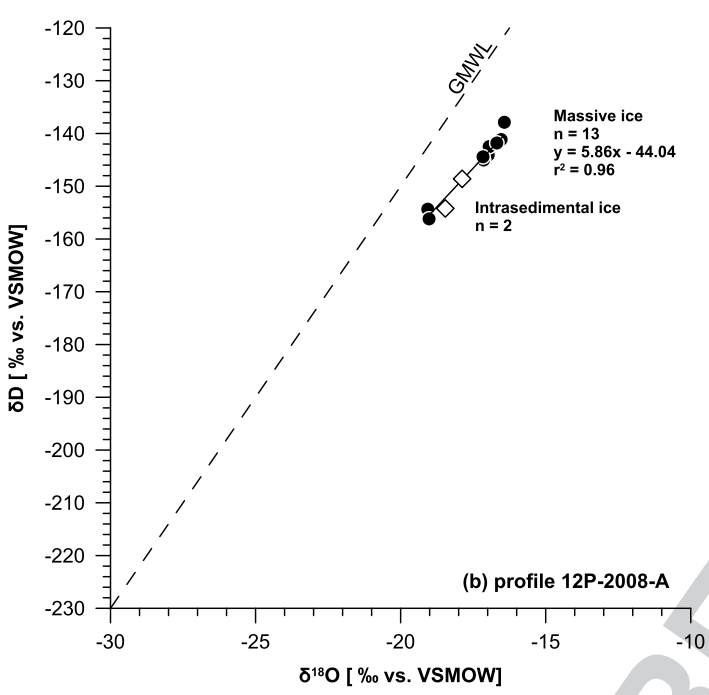

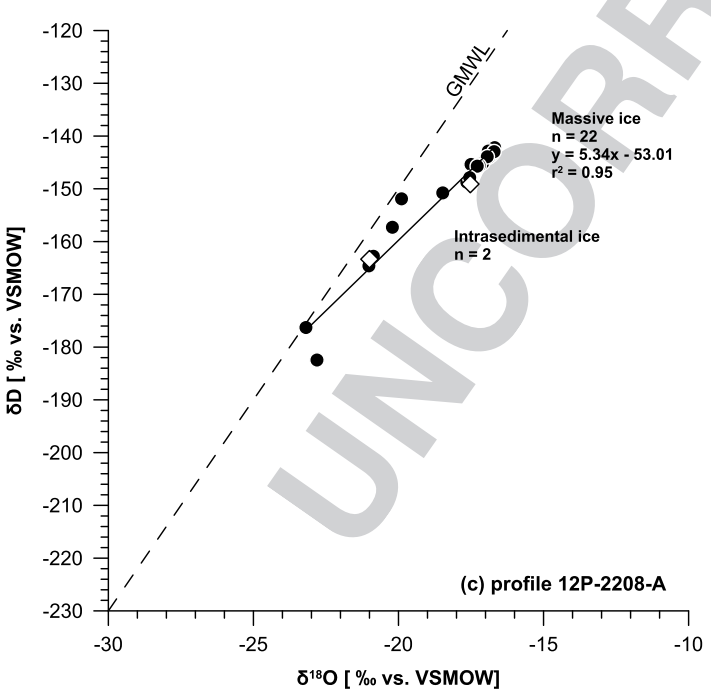

FIGURE $5 \quad \delta^{18} \mathrm{O}$ and $\delta \mathrm{D}$ data of ice samples from profiles (a) $12 \mathrm{P}$ 1908-A, (b) 12P-2008-A and (c) 12P-2208-A. Wedge-ice data are gives as shaded triangles, intrasedimental ice data are given as open diamonds and massive ice data are given as filled circles. The global meteoric water line (GMWL) is given as a dotted line [Colour figure can be viewed at wileyonlinelibrary.com]

pingo ice shows $\delta^{18} \mathrm{O}$ of $-17.2 \pm 0.8 \%$ o, $\delta \mathrm{D}$ of $-145 \pm 5.0 \%$ ond $\mathrm{d}$ excess of $-7.1 \pm 2.0 \%$ o (Figure $5 b$, Table 2 ). The EC of the pingo ice varies between 32 and $203 \mu \mathrm{S} / \mathrm{cm}$, but reaches higher values of up to $1068 \mu \mathrm{S} / \mathrm{cm}$ near the contact with sediment (Figure S6c). Massive ice samples close to the upper and lower sedimentary boundaries (Figure S1b) exhibit higher concentrations of major cations (calcium, magnesium, sodium) and anions (chloride, hydrogen carbonate) except for sulfate, which is low at the lower sediment contact (Figure S6, Table S1). The $\mathrm{pH}$ values range between 6.0 and 7.4 (Figure S6d).

\subsection{3 | Profile 12P2208-A}

The profile 12P-2208-A exhibits parts of the pingo ice core and overlying sediments in the eastern part of the outcrop between about 4 and $10 \mathrm{~m}$ a.l.I. over a lateral distance of about $30 \mathrm{~m}$ (Figures 3 and S1c, d). Most samples (12P-2208-A-01 to -23$)$ were collected in vertical and horizontal lines (Figure S1c).

The enclosing deposits of the massive ice are slightly bedded grey-brown and light brown poorly sorted sandy silts with rare wood, root and peat inclusions. The sediments have a bimodal grain-size distribution (Figure S4). The cryostructure is mainly irregular reticulate. OM characteristics show rather low variation in TOC (2.9-7.2 wt\%), $\mathrm{C} / \mathrm{N}(12.3-16.1)$ and $\delta^{13} \mathrm{C}(-28.2$ to $-27.8 \%$ ) (Figures 4, S5). Radiocarbon dates exhibit early Holocene ages between about 10.1 and $8.5 \mathrm{cal}$ kyr BP and one redeposited subrecent age of $227 \mathrm{cal}$ yr BP (Figure 4, Table 1).

The massive ice differentiates into two types. One is characterized by rather small crystal sizes $(5-10 \mathrm{~mm})$ with numerous small bubbles (< $1 \mathrm{~mm}$ in diameter) nonregularly distributed, which cause the whitish appearance; sediment inclusions up to $1 \mathrm{~cm}$ thick were detected and horizontal layering was partly visible (Figure $2 \mathrm{e}, \mathrm{f}$ ). The second type has larger crystal sizes (20 $\times 30 \mathrm{~mm}$ up to $40 \times 70 \mathrm{~mm}$ ) and appears bluish and clear (Figure $2 \mathrm{e}, \mathrm{g}$ ). It includes rounded and larger bubbles $(0.5-2 \mathrm{~mm}$ in diameter) in subvertical and horizontal layers and elongated bubbles (1-2 cm long) in subvertical direction (Figure 2g). Additionally, massive ice was sampled in three "windows" located between 1.5 and $3 \mathrm{~m}$ a.l.I. (Figure S1d). The stable water isotope composition of the massive ice shows a wider scatter if compared to data from profiles 12P1908-A and 12P-2008-A with average values of $-18.3 \pm 2.1 \%$ o for $\delta^{18} \mathrm{O},-150.5 \pm 11.4 \%$ o for $\delta \mathrm{D}$ and $-4.3 \pm 6.1 \%$ o for $d$ excess (Figure $5 \mathrm{c}$, Table 2). Stable isotope data of intrasedimental ice from above and within the massive ice (samples 12P-2208-A-04 and -14) fall within the range of the massive ice data (Figure $5 \mathrm{c}$ ). The EC of the massive ice within this part of the exposure varies only between 45 and $116 \mu \mathrm{S} / \mathrm{cm}$ (Figure S6c, Table S1). The hydrochemical composition of the 12P-2208-A ice shows higher values for calcium and sulfate, especially in the upper part of the profile. Other major ion concentrations are comparable to those of the $12 \mathrm{P}-2008-\mathrm{A}$ pingo ice (Figure $\mathrm{S} 6 \mathrm{a}, \mathrm{e})$. The $\mathrm{pH}$ is mainly neutral with values between $\mathrm{pH} 6.5$ and $\mathrm{pH} 7.2$ (Figure S6d).

\subsubsection{Sedimentary and organic matter characteris- tics of all profiles}

The granulometric data from all three profiles show mainly bimodal grain size distributions with peaks in the clay and the fine sand fractions (Figure S4). Similar patterns have been observed in shallow 
thermokarst lakes with little flow and the repeated deposition of sand particles from shore slump activity. ${ }^{53}$ The sediments within and surrounding the massive ice are assumed to be of lacustrine origin. The $\mathrm{C} / \mathrm{N}-\delta^{13} \mathrm{C}$ relationship reflecting $\mathrm{OM}$ origin ${ }^{54}$ shows a narrow range in the transition from lacustrine algae to terrestrial plants (Figure S5). In addition, the TOC $-\mathrm{C} / \mathrm{N}$ relationship indicates a moderate correlation $\left(r^{2}=0.63\right)$ of modestly to highly decomposed OM as typical for lacustrine deposition in thermokarst environments. ${ }^{55}$ The early Holocene radiocarbon dates of deposits enclosing the massive ice (ranging from 10.3 to 8.5 cal kyr BP; Table 1) indicate the depositional age of the lacustrine sediments, which have been present before the onset of pingo formation.

\section{4 | Paleo-ecology of profile 12P-1908-A}

\subsection{1 | Pollen and palynomorphs}

Pollen and palynomorph assemblages from profile 12P-1908-A are subdivided into two pollen zones (PZ-I and PZ-II) of which PZ-II is further sectioned into two subzones (P-Ila and P-IIb; Figure S7a). In total, 33 pollen and spore taxa were identified. Most of the pollen grains and spores were well preserved. Spores are generally rare in the record, but Pediastrum remains are present. Pollen zone P-I (10.5-8 cal kyr BP; $1.7-5 \mathrm{~m}$ a.l.I.) is notable for high amounts of Betula sect. Nanae (40-45\%) and Alnus fruticosa (25-45\%) pollen, and relatively low contents of Cyperaceae (5-10\%) and Poaceae (4-8\%) pollen (Figure 6a). F6 Larix pollen and Encalypta spores are present. P-I is interpreted as a regional representation of southern shrub-tundra. ${ }^{56}$ Shrub birch and alder dominated the vegetation and larch occurred as isolated trees within the vegetation cover. A summer climate slightly warmer than today is assumed for P-I. Pollen zone P-lla (8-5 cal kyr BP; 5-6.3 m a.l.I.) shows a decrease in Alnus fruticosa (up to 17\%) (Figure S6a), and the disappearance of Larix. Poaceae and Cyperaceae pollen dominate among herb taxa. Ericales pollen reaches 5\%. Artemisia, Potentilla and Rubus chamaemorus pollen are present. Pediastrum reaches a maximum of $40 \%$. The decrease in shrub alder and birch and disappearance of larch indicate climate cooling. The regional-scale vegetation is interpreted as grass and shrub tundra. As in PZ-Ila the uppermost pollen zone P-Ilb (5-3.5 cal kyr BP, above $6.3 \mathrm{~m}$ a.I.I.) is marked by lower counts in both Betula sect. Nanae and Alnus fruticosa pollen as compared to PZ-I. Cyperaceae (20-40\%) and Poaceae (10\%) pollen dominate (Figure S7a). Rosaceae has higher counts than in P-lla and Comarum, Rubus chamaemorus, Artemisia pollen and Sphagnum spores are present. Based on changes in intrazonal taxa, ie, the decrease in Pediastrum and the increase in Cyperaceae, P-Ilb is interpreted as a local vegetation change in response to paludification and acidification of the thermokarst lake basin. Pediastrum remains are absent in peaty layers at 1.7 and $4.6 \mathrm{~m}$ a.l.I., but present in sand and silt layers of PZ-IIb indicating aquatic deposition.

\subsection{2 | Testaceans (testate amoebae)}

In total, 30 testacean taxa were identified in ten samples of profile 12P-1908-A (Figure S7b), including sphagnobiontic, soil-eurybiontic and hydrobiontic species. The last of these constitute the largest part of the identified taxa, 24 in total. Count numbers range between seven and 45 specimens per sample and are therefore plotted and 


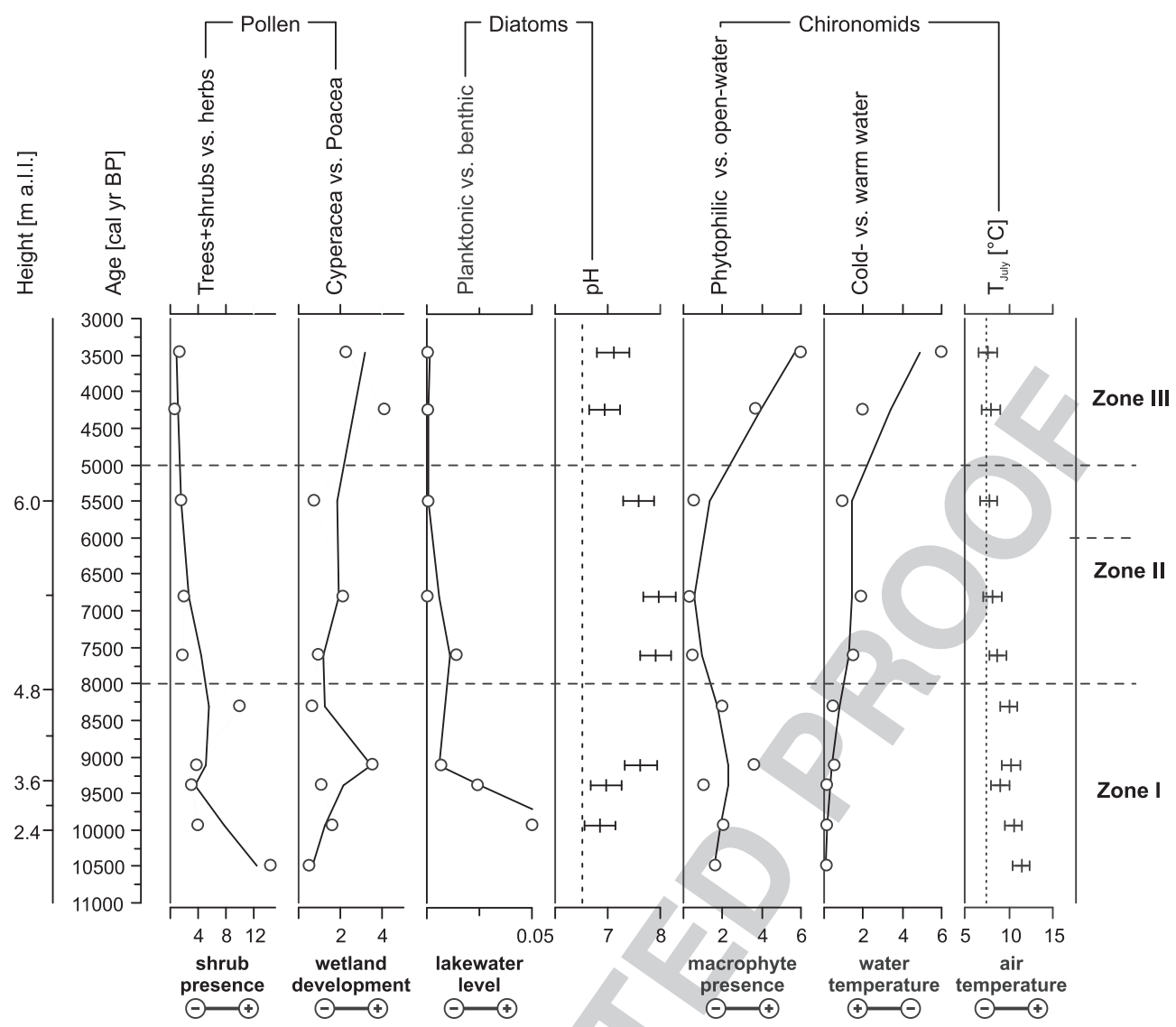

FIGURE 6 Summary of paleo-ecological data, including pollen-based ratios of Cyperaceae vs. Poaceae and trees and shrubs vs. herbs, diatombased ratio of planktonic vs. benthic species and $\mathrm{pH}$ reconstruction, and chironomid-based cold-stenoterm vs. warm-stenoterm taxa, phytophilic vs. free-water taxa and $T_{\text {July }}$ reconstruction. Black lines indicate LOESS 0.5 smoothing of the data

interpreted as presence-absence information. The testacean data of the lowermost testacean zone T-I (10.5-8 cal kyr BP; 1.7-5 m a.I.I.) indicate an aquatic habitat based on the prevailing presence of 11 hydrobiontic species mainly of the genera Centropyxis and Difflugia (Figure S7b). Sphagnum moss inhabiting Trigonopyxis arcula and Centropyxis aculeata indicate wet conditions. In T-II (8-5 cal kyr BP; 5-6.3 $\mathrm{m}$ a.l.I.) the number of taxa decreases to 11 , nine of which belong to hydrobiontic and two to soil-eurybiontic species. Sphagnobiontic species are lacking. The species composition changes at subspecies level and aquatic conditions are still present. The uppermost zone T-III (5-3.5 cal kyr BP, above $6.3 \mathrm{~m}$ a.I.I.) has 16 taxa, including 14 hydrobionts. The eurybiontic Trinema lineare and the sphagnobiontic Centropyxis aculeata are present. Shallow-water to semi-aquatic conditions are assumed.

\subsection{3 | Diatoms}

In eight samples from profile 12P-1908-A, 107 diatom taxa were found, while in assemblages of the short core of the modern lake sediments (Figure S2) 86 taxa were present with a floristic similarity between both records of 50.8\%. In zone D-I (10.5-8 cal kyr BP; 1.7$5 \mathrm{~m}$ a.l.I.), 41 taxa were identified. The number of species increased from 15 per sample in the lower part of the zone to 28 at the top. In the lower part of D-I, the highest percentage of planktonic and alkalibiontic species was marked, with the benthic Cymbopleura inaequalis associated with macrophytes as the dominant species (Figure S7c). The planktonic Aulacoseira ambigua indicates considerable water depth of a mature thermokarst lake around 10 cal kyr BP, which decreases thereafter. In the middle and upper parts of D-I, proportions of mesohalobic, halophilic and streaming-water species increase, and alkaliphilic taxa replace alkalibiontics. The largest share of thermophilic species is observed in the upper part of D-I. Another dominant species, S. pinnata, appears and the number of subdominant Martyana martyi, Amphora libyca and Gyrosigma acuminatum increases. The reconstructed $\mathrm{pH}$ varies from 6.9 to 7.6 in D-I (Figure 6). The diatom assemblages of $D-I$ reflect warming, increasing evaporation and ion content, and decreasing water level of a mature thermokarst lake with a littoral zone of macrophytes. Smaller species reflecting the instability of the environment replace large-sized dominant species in zone D-I. Diatom zone D-II (8-6 cal kyr BP; 5-5.7 $\mathrm{m}$ a.I.I.) exhibits a gradual increase in the species number (45 in total, ranging from 27 to 30 per sample) and increasing shares of benthic and planktonic-benthic species (Figure 6). The highest percentage of boreal species not adapted to streaming water and the lowest percentage of mesohalobic and halophilic species is observed in D-II. Thermophilic species are lacking while eurythermal and cold-water species appear in the upper part of zone D-II. The reconstructed $\mathrm{pH}$ varies little from 7.9 to 8 (Figure 6). S. pinnata dominates the lower part of D-II while Navicula vulpina has high counts in the upper part (Figure S7c). Diatom assemblages of DII reflect cooling of a still-water shallow lake with reduced ion content. 
In D-III (6-3.5 cal kyr BP, above $6.3 \mathrm{~m}$ a.l.I.) the maximum species number (51 in total, ranging from 26 to 33 per sample) is notable. D-III is characterized by the highest share of planktonic-benthic and acidophilic species indicating shallow water and decreasing $\mathrm{pH}$ (Figure 6). Eurythermal and cold-water species prevail while the share of boreal species is reduced. The reconstructed $\mathrm{pH}$ drops from 7.6 to 6.9. The major dominant species in D-III is S. pinnata. The diatom record of D-III reflects colder conditions than in D-II and D-I. The existence of a shallow lake remnant or paludified pond with low ion content is assumed.

\subsection{4 | Chironomids}

A total of 420 head capsules, which belong to three subfamilies (Chironominae, Orthocladiinae, Tanypodinae), were examined in ten samples from profile 12P-1908-A. Chironomid zone C-I (10.5-8 cal kyr BP; 1.7-5 $\mathrm{m}$ a.I.I.) is diverse and represented by taxa indicative of cool to temperate conditions (C. anthracinus-type, O. consobrinustype, Micropsectra insignilobus-type), of warm conditions (Cricotopus laricomalis-type, Parakiefferiella bathophila-type) and taxa associated with macrophytes. Most of the phytophilic taxa appear only in C-I: Zalutschia mucronata-type, Z. zalutschicola-type, Endochironmus impar-type, Polypedilum sordens-type and Glyptotendipes barbipes-type. In the upper part of C-I (after about 9 cal kyr BP), a high number of taxa tolerant to acidification and phytophilic taxa of $P$. penicillatus-type and $P$. sordidellus-type occur (Figure $6 \mathrm{~d}$ ). The reconstructed mean air $T_{\text {July }}$ reaches $10.2-11.4^{\circ} \mathrm{C}$. The water body was vegetated by macrophytes. High abundances of acidophilic taxa indicate the start of paludification at the lakeshore. Chironomid zone C-II (8-5 cal kyr BP; 5-6.3 $\mathrm{m}$ a.I.I.) shows a decline in taxonomic diversity after $8 \mathrm{cal}$ kyr BP. The abundance of the $C$. anthracinus-type is highest in the record. Many phytophilic taxa disappear from the record and the taxa indicative of warm conditions are replaced by the cold-stenotherm taxa (Sergentia coracina-type and T. lugens-type) indicating cooling and decrease of the macrophyte belt. Summer climate cooling is reconstructed with mean $T_{\text {July }}$ of $7.7-8.7^{\circ} \mathrm{C}$ (Figure 6). Chironomid diversity in zone C-III (5-3.5 cal kyr BP, above $6.3 \mathrm{~m}$ a.I.I.) further decreases with a strong shift in the taxonomic composition. In zone C-III dominant taxa are phytophilic (Cricotopus intersectus-type), tolerant to acidification (P. penicillatus-type, Zalutshia type B) and are associated with very shallow water in the littoral part of the lakes (Limnophyes-Paralimnophyes and ParaphaenocladiusParametriocnemus). The latter two taxa can survive even under semi-terrestrial conditions. The reconstructed $T_{\text {July }}$ of C-III with 7.6$7.9^{\circ} \mathrm{C}$ is close to modern $T_{\text {July }}$ of $7.5^{\circ} \mathrm{C}$ (Figure 7). The prevalence of $\mathbf{F} 7$ shallow-water or semi-terrestrial taxa in C-III suggests ongoing disappearance of the lake.

\section{4 | DISCUSSION}

\section{1 | The early to mid-Holocene thermokarst lake archive (10.5-3.5 cal kyr BP)}

The Holocene sequence obtained in profile 12P-1908-A captures thermokarst lake deposits that accumulated before formation of the studied pingo. The oldest date of $10489 \mathrm{cal}$ yr BP from the peat underlying the lake sediment probably represents the early Holocene thermokarst onset in a palustrine environment with increasing wetness and beginning of thaw subsidence due to ground-ice melt leading to the formation of the thermokarst lake. The timing of this thermokarst initiation falls into the age range from 14 to $9 \mathrm{cal} \mathrm{kyr}$ obtained from basal peat of thermokarst basins in Beringia ${ }^{2}$ reflecting lateglacial to early Holocene warming. According to the established age-height relationship (Figure S3), continuous sedimentation within the lake is assumed between about 10.5 and $3.5 \mathrm{cal} \mathrm{kyr} \mathrm{BP.}$

The paleo-environmental inventory of early to mid-Holocene deposits exposed in profile 12P-1908-A exhibits species-rich floral and faunal assemblages. The species distribution of each studied group allows for zonation into three ecological zones (Table 3, Figure 6). The T3 micropaleontological records reflect a thermokarst lake system with changing conditions in water level, air and water temperature and water chemistry over time corresponding to Holocene variations in climate conditions superimposed by local controls ${ }^{32,53}$ (Table 3). All paleontological proxy data differentiate the lowermost interval between about 10.5 and $8 \mathrm{cal}$ kyr BP, as ecological zone I. Warmerthan-today mean $T_{\text {July, }}$, shallowing of the water body, increasing ion content and neutral $\mathrm{pH}$ are reflected in proxy data. The lake littoral

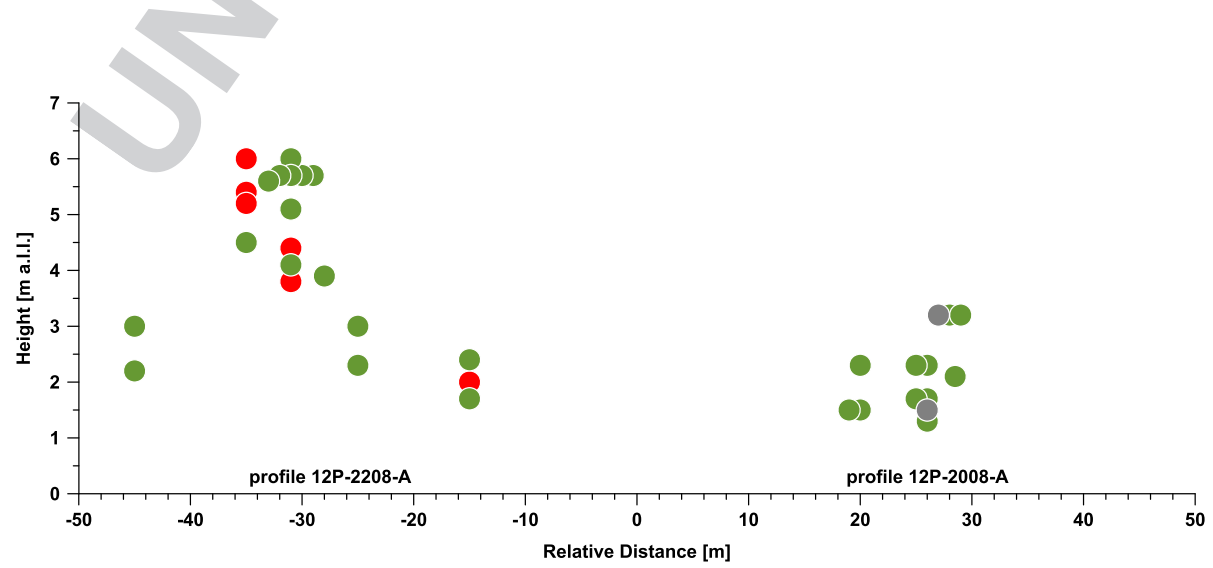

FIGURE 7 Spatial distributions of massive-ice properties (electrical conductivity [EC], pH, anions, cations, stable-isotope signature; Table S1) according to agglomerative hierarchical clustering. Two clusters are well separated (green and red; Figure S8a, b) and two samples could not be assigned to any cluster (gray) [Colour figure can be viewed at wileyonlinelibrary.com] 
TABLE 3 Compiled interpretation of early to mid-Holocene paleontological proxy data from profile 12P-1908-A

\begin{tabular}{|c|c|c|c|}
\hline Period & Early Holocene & Early to mid-Holocene & Mid-Holocene \\
\hline Age & $11-8$ cal kyr BP & $8-6(5)$ cal yr BP & 6 (5)-3.5 cal kyr BP \\
\hline Pollen & $\begin{array}{l}\rightarrow \text { southern shrub tundra } \\
\rightarrow \text { dominating Betula and Alnus } \\
\rightarrow \text { Larix present } \\
\rightarrow \text { slightly warmer than today }\end{array}$ & $\begin{array}{l}\rightarrow \text { grass-shrub tundra } \\
\rightarrow \text { decreased Betula and Alnus } \\
\rightarrow \text { Larix absent } \\
\rightarrow \text { climate cooling }\end{array}$ & $\begin{array}{l}\rightarrow \text { sedge-shrub tundra } \\
\rightarrow \text { decreased Betula and Alnus } \\
\rightarrow \text { Larix absent } \\
\rightarrow \text { close-to-modern climate }\end{array}$ \\
\hline Testacean & $\begin{array}{l}\rightarrow \text { diverse hydrobionts } \\
\rightarrow \text { aquatic conditions }\end{array}$ & $\begin{array}{l}\rightarrow \text { less diverse hydrobionts } \\
\rightarrow \text { aquatic conditions }\end{array}$ & $\begin{array}{l}\rightarrow \text { diverse hydrobionts } \\
\rightarrow \text { semi-aquatic conditions }\end{array}$ \\
\hline Diatoms & $\begin{array}{l}\rightarrow \text { highest share of planktonic species } \\
\rightarrow \text { highest share of alkalibiontic and } \\
\text { thermophilic species } \\
\rightarrow \text { decreasing water level } \\
\rightarrow \text { increasing ion content } \\
\rightarrow \text { pH 6.9-7.6 } \\
\rightarrow \text { warming }\end{array}$ & $\begin{array}{l}\rightarrow \text { no planktonic species } \\
\rightarrow \text { increasing benthic and planktonic- } \\
\quad \text { benthic species } \\
\rightarrow \text { highest share of boreal species } \\
\rightarrow \text { shallow water } \\
\rightarrow \text { decreasing ion content } \\
\rightarrow \text { pH 7.9-8 } \\
\rightarrow \text { cooling }\end{array}$ & $\begin{array}{l}\rightarrow \text { no planktonic species } \\
\rightarrow \text { highest share of benthic-planktonic species } \\
\rightarrow \text { highest share of acidophilic species } \\
\rightarrow \text { shallow water } \\
\rightarrow \text { decreased ion content } \\
\rightarrow \text { pH } 6.9-7.6 \\
\rightarrow \text { cooling }\end{array}$ \\
\hline Chironomids & $\begin{array}{l}\rightarrow \text { high diversity } \\
\rightarrow \text { dominating phytophilic taxa } \\
\rightarrow \text { lake with well-established macrophyte } \\
\quad \text { littoral } \\
\rightarrow \text { present warm-stenotherm taxa } \\
\rightarrow T_{\text {July }} 10.2-11.4^{\circ} \mathrm{C}\end{array}$ & $\begin{array}{l}\rightarrow \text { decreasing diversity } \\
\rightarrow \text { decreasing phytophilic taxa } \\
\rightarrow \text { lake with decreasing macrophyte } \\
\quad \text { littoral } \\
\rightarrow \text { cold-stenotherm replace warm- } \\
\quad \text { stenotherm taxa } \\
\rightarrow \text { mean } T_{\text {July }} 7.7-8.7^{\circ} \mathrm{C}\end{array}$ & $\begin{aligned} \rightarrow & \text { decreasing diversity } \\
\rightarrow & \text { dominant taxa tolerant to acidification } \\
\rightarrow & \text { shallow water to semi-aquatic with present } \\
& \text { macrophytes } \\
\rightarrow & \text { present cold-stenotherm taxa } \\
\rightarrow & \text { mean } T_{\text {July }} 7.6-7.9^{\circ} \mathrm{C}\end{aligned}$ \\
\hline
\end{tabular}

zone was vegetated by macrophytes and the regional vegetation was southern shrub tundra. The deduced warmest conditions during the early Holocene between about 10.5 and 8 cal kyr BP in the Kolyma Lowland probably correspond to earlier findings along a north-tosouth transect at the Lena River, where lake sediments were used to reconstruct summer climate. ${ }^{57}$ Biskaborn et al. ${ }^{57}$ showed warmest conditions during the early Holocene in the northernmost locations of the transect, in the Lena Delta. However, detailed Holocene climate reconstructions along the Kolyma River are lacking, and the pattern observed along the Lena River cannot be proven.

The ecological zone II spans from about 8 to 5 cal kyr BP according to pollen, testacean and chironomid data while diatom data support a termination of zone II at about 6 cal kyr BP. Summer cooling is mirrored by a vegetation change to grass-shrub tundra with decreased Alnus and Betula counts, and lacking Larix. $T_{\text {July }}$ reached 7.7-8. $7^{\circ} \mathrm{C}$ and cold-adapted aquatic species replaced warm-adapted ones. The lake was shallow and with a decreased macrophyte belt.

The ecological zone III spans from about 6-5 cal kyr BP to $3.5 \mathrm{cal}$ kyr BP. Sedge-shrub tundra prevailed at least in the surroundings of the lake. $T_{\text {July }}$ reached close-to-modern values: $7.6-7.9^{\circ} \mathrm{C}$ Semi-aquatic conditions, low ion content and decreasing $\mathrm{pH}$ indicate disappearance of the lake and the beginning of paludification, which was the precondition for pingo formation triggered by refreezing of the talik beneath the lake.

\subsection{The late Holocene pingo and wedge ice archives (3.5 cal kyr BP to present)}

Until now, there are only few records from pingo ice stable isotope and hydrochemical signatures. ${ }^{58-60}$ Previous studies of pingo ice suggest vertical gradients in stable-isotope values, which depend on the original isotopic composition and availability of migrating water in the talik, the latter resulting in varying equilibrium conditions and isotopic fractionation during freezing. ${ }^{59}$ General trends and stages are described as follows ${ }^{59}$ : (1) rapid freezing of water in the basin sediments after drainage initiates ice formation with increasing $\delta^{18} \mathrm{O}$ and $\delta D$ and decreasing $d$ excess; (2) talik water migration toward the freezing front under hydrostatic conditions results in ice segregation and intrusion, which is shown in large variation in $\delta^{18} \mathrm{O}, \delta \mathrm{D}$ and $\mathrm{d}$ excess; and (3) freezing of an increasingly limited volume of talik water under hydrostatic (equilibrium) conditions results in a decrease in $\delta^{18} \mathrm{O}$ and $\delta D$ and increase in $d$ excess which follows the Rayleigh-type fractionation between water and ice. The shrinking reservoir becomes increasingly depleted in heavy isotopes as freezing continues. ${ }^{61}$

Neither a clear gradient nor a distinct spatial pattern of stable isotope and hydrochemical data in the pingo ice are seen in the presented data (Figure S6).

An agglomerative hierarchical cluster analysis comprising stableisotope and hydrochemical variables of the 35 samples from the massive ice reveals two well-separated clusters and two samples that could not be assigned to any cluster (Figure S8). Of those notclustered samples, sample 12P-2008-A-06-PI has the highest values in EC (Figure S6c), potassium, magnesium, sodium, chloride, sulfate and hydrogen carbonate (Figure S6), while 12P-2008-A-12-PI has the highest $\mathrm{pH}$ (Figure $\mathrm{S} 6 \mathrm{~d}$ ), aluminum and fluoride values and the second highest magnesium, sodium, iron and chloride, hydrogen carbonate values (Figure S6, Table S1). These two ice samples are in close contact with the surrounding sediment and therefore strongly affected by sediment pore water. If we apply the results of the cluster analysis to the lateral distribution of samples, we detect two areas of common chemical properties (Figure 7).

The red cluster is well distinguishable in stable isotope signature from the green cluster, because of the lower isotope ratios and the higher $d$ excess (Figure 8): $\delta^{18} \mathrm{O}(-21.3 \pm 1.4 \%), \quad \delta D$ F8 $(-165.9 \pm 11.5 \%)$ and $d$ excess $(4.9 \pm 3.2 \%$ o). Furthermore, the red cluster shows different slopes of 8.13 in the $\delta^{18} \mathrm{O}-\delta \mathrm{D}$ relationship $\left(r^{2}=0.92\right)$ and of 0.09 in the $\delta D-d$ excess relationship $\left(r^{2}=0.12\right)$ (Figure 8) if compared to the green cluster with a $\delta^{18} \mathrm{O}-\delta \mathrm{D}$ slope of 

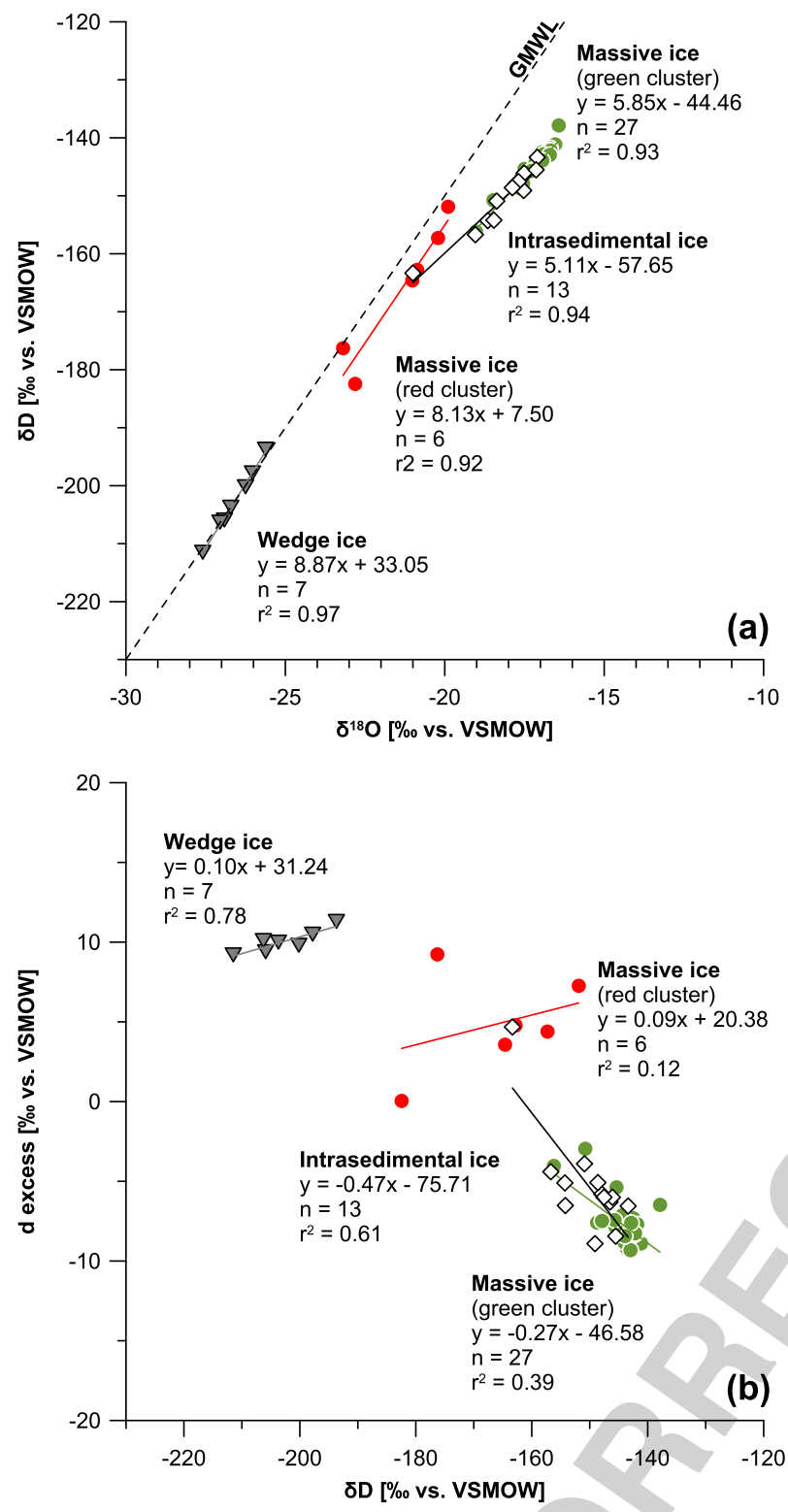

FIGURE $8 \quad \delta^{18} \mathrm{O}, \delta \mathrm{D}$ and $\mathrm{d}$ excess data of ice samples combined from all profiles as wedge ice (shaded triangles), intrasedimental ice (open diamonds) and massive ice (red and green circles) in a (a) $\delta^{18} \mathrm{O}-\delta \mathrm{D}$ biplot and (b) $\delta \mathrm{D}$-d excess biplot [Colour figure can be viewed at wileyonlinelibrary.com]

$5.85\left(r^{2}=0.93\right)$ and a $\delta D-d$ excess slope of $-0.27\left(r^{2}=0.39\right)$. The $\delta^{18} \mathrm{O}-\delta \mathrm{D}$ slope of the red cluster samples is close to the global meteoric water line (GMWL) and the slightly positive slope in $\delta \mathrm{D}$-d excess points to an origin different from the massive pingo ice of the green cluster. Surface water from a meteoric water source that entered the massive pingo ice body might explain the isotopic signature of the red cluster. Dilation cracks might have formed, filled with surface water and contributed to the massive ice growth during different episodes. ${ }^{4}$ The spatial distribution (Figure 7) at different heights and the relatively heavy stable isotope composition (Figure 8) of the red cluster samples within profile 12P-2207-A make wedge-ice growth on the slope of the developing pingo unlikely to explain the observed pattern and stable isotope composition. The red cluster samples consist of whitish ice, which shows layers, sediment inclusions, small ice crystals $(5-10 \mathrm{~mm})$ and many small and nonregularly distributed air bubbles ( $<1 \mathrm{~mm}$ in diameter). The red cluster further differs from the green cluster in potassium, sulfate, iron and magnesium contents (Figure S6). The ice of the green cluster is interpreted as pingo massive ice as the data point to closed-system freezing of talik water by a slope well below the GMWL in $\delta^{18} \mathrm{O}-\delta \mathrm{D}$, a negative slope in $\delta \mathrm{D}-\mathrm{d}$ excess (Figure 8) and some variation in $\delta^{18} \mathrm{O}(-17.1 \pm 0.6 \%)$, $\delta \mathrm{D}$ $(-144.5 \pm 3.4 \%$ o $)$ and $d$ excess $(-7.7 \pm 1.5 \%$ o). The available pingo ice data were obtained from a lateral position and do not represent a vertical profile of the central part of the ice core. Thus, the entire freezing of the pingo ice and respective variations in stable isotope composition are not captured in the present record. However, comparable slopes as in the green cluster were observed for mature and final stages of slow equilibrium freezing of pingo ice: 5.11 in section 2 of Pestsovoye Pingo, 5.63 in section 3 of Weather Pingo ${ }^{59}$ and 5.84 in section 4 of Arsain Pingo. ${ }^{58}$ During equilibrium freezing of water, the resultant ice samples are aligned along a freezing slope that will be lower than the GMWL. Jouzel and Souchez ${ }^{62}$ observed that the slope of the freezing line depends on the initial isotopic composition, with the more depleted waters producing a lower slope value. The initial $\delta$-value of the parent water is the intercept between the freezing slope and the local meteoric water line (LMWL) or GMWL, ${ }^{62,63}$ which is here at about $-25.5 \% \circ \delta^{18} \mathrm{O}$ and $-193 \%$ o $\mathrm{D}$ (Figure 8a). Further information is provided by an examination of the $\delta D-d$ excess relationship. A negative relationship between $d$ excess and $\delta D$ $\left(y=-0.27-46.58 ; r^{2}=0.39\right)$ is found because the freezing slope has a lower value than the GMWL (Figure $8 b$ ). Here, $d$ excess variability is a result of the freezing conditions (freezing rate, boundary layer thickness, percentage of freezing of the reservoir). ${ }^{63}$ As freezing progresses, the $\delta \mathrm{D}$ values of the ice become progressively lower. This is accompanied by a concurrent increase in d excess values (Figure 8b) and might therefore account for the initial stage of closed-system freezing. ${ }^{64}$ The deviation from the theoretical freezing slope is interpreted as expression of differing isotopic fractionation during stepwise segregation of the pingo ice while refreezing of the talik. It is also possible that multiple smaller ice bodies developed in the single pingo, having their own isotopic boundary conditions, but taken together it provides a coherent picture of pingo development. Intrasedimental ice values generally fall within the range of the massive pingo ice values (Figure 5). Such similarity is reasonable because both ice types belong together genetically, as both originate from ice segregation in the same talik and the same parent water.

Based on its stratigraphic position the ice wedge topping profile 12P-1908-A is of late Holocene age and indicates permafrost aggradation during that time. Its stable-water isotope composition with narrow ranges of $\delta^{18} \mathrm{O}(-26.6 \pm 0.6 \%)$, of $\delta D(-202.7 \pm 5.5 \%)$, its $d$ excess of $10 \pm 0.7 \%$ and its position close to the GMWL (slope of 8.87; Figure 8a) confirms the wedge-ice water source from precipitation. These stable-water isotope parameters further corroborate that the wedge-ice signal from winter season precipitation in the region during the late Holocene averages about $-26.6 \%$ in $\delta^{18} \mathrm{O}$, which is assumed to be mainly influenced by Pacific moisture. In contrast, the winter precipitation in the Laptev Sea region is thought to be mainly fed by Atlantic moisture, ${ }^{65}$ leading to a spatial pattern in late Holocene wedge-ice data with most depleted isotope values in the easternmost location along a west-to-east transect. This corresponds to the 
continental effect in atmospheric precipitation ${ }^{34}$ as seen in decreasing $\delta^{18} \mathrm{O}$ from Taymyr Peninsula ${ }^{66}$ (mean $\delta^{18} \mathrm{O}$ of $-23.0 \%$ ), to the Lena Delta $^{67,68}$ (mean $\delta^{18} \mathrm{O}$ of $-24.6 \%$ ) and to Bykovsky Peninsula ${ }^{65}$ (mean $\delta^{18} \mathrm{O}$ of -28.5 to $-26.1 \%$ ). The meeting influence of moisture originating from both the Atlantic and the Pacific Oceans is found in the Dmitry Laptev Strait region ${ }^{69}$ (mean $\delta^{18} \mathrm{O}$ of -25.4 to $-25.0 \%$ ).

The late Holocene terrestrial landscape evolution of the Kolyma permafrost aggradation, which is especially expressed in ground-ice formation within drained thermokarst basins and on floodplains. Pingo growth and the formation of ice-wedge polygons shaped the topography on different scales.

\subsection{The modern landscape of the Kolyma Lowland}

A remote sensing-based mapping of the Kolyma Lowland southwest of the delta estimates that $65 \%$ of the study area is covered by Holocene thermokarst basins. ${ }^{70}$ A similar distribution of extensive thermokarst-lake basins is expected in the Kolyma Delta and the Khalerchinskaya Tundra, where comparable studies are lacking. ${ }^{71}$ Grosse and Jones ${ }^{17}$ mapped about 700 pingos in the Kolyma Lowland $\left(150.7-162.5^{\circ} \mathrm{E}\right)$, including the delta. However, the pingo "Shirokovsky Kholm" was not part of their study, because it is not expressed on topographical maps at a $200-\mathrm{km}$ scale. This indicates a larger number of yet undocumented pingos in the Kolyma Lowland. Pingo-induced relief inversion frequently led to renewal of thermokarst lakes, and secondary late Holocene thermokarst developed in pre-defined basins of early Holocene age where wedge-ice melt occurred.

Main areas of the Kolyma Lowland such as the Khalerchinskaya Tundra and the Kolyma Delta are shaped by intense thermo-erosion and thermokarst as expressed by channels, basins and shallow lakes. Pingos are common features reaching $150-200 \mathrm{~m}$ in diameter and 15-20 m in height, ${ }^{19}$ matching the dimensions of the studied pingo (Figure 1e). Ice-wedge polygons occur commonly in wetlands surrounding the lakes and indicate permafrost aggradation during the late Holocene.

The host material is mainly silt and silty sand of Holocene marine and alluvial origin in the Kolyma Delta ${ }^{22}$ and of late Holocene limnicQ6 palustrine or eolian origin overlying Last Glacial Maximum alluvial and constant paludification at the lakeshore. In contrast, the Kolyma River Lowland is characterized by widely distributed processes of floodplain is dominated by predominantly lake expansion dynamics. While the Khalerchinskaya Tundra might represent an older delta formation, comparable to the Arga Complex (second river terrace) of the Lena Delta, ${ }^{73}$ and thermokarst there already started during lateglacial to early Holocene warming, the recent and modern parts of the Kolyma Delta formed during the late Holocene and consequently thermokarst lakes here are much younger. In this context, the early Holocene age of the thermokarst lake deposits in the pingo exposure align it to the Khalerchinskaya Tundra. The studied complete inventory of primary and secondary thermokarst and of pingo and assumed to be representative for postglacial landscape evolution in the Kolyma Lowland.

\section{5 | CONCLUSIONS}

Early to mid-Holocene lacustrine deposits, and late Holocene wedge ice and pingo ice represent a comprehensive archive of permafrost degradation and aggradation features in the Kolyma Lowland. Main patterns in Holocene climate variations and permafrost response are preserved in the proxy records. Thermokarst lake and palustrine deposits dated from about 10.5 to $3.5 \mathrm{cal}$ kyr BP differentiate into three paleo-ecological periods. Warmest summer conditions are reconstructed for the early Holocene between 10.5 and $8 \mathrm{cal}$ kyr BP. Vegetation changed from southern shrub tundra to grass-shrub and sedge-shrub tundra following a $T_{\text {July }}$ cooling from $11.4-10.2^{\circ} \mathrm{C}$ (10.5-8 cal kyr BP) to $8.7-7.7^{\circ} \mathrm{C}(8-5 \mathrm{cal} k y r \mathrm{BP})$ and $7.9-7.6^{\circ} \mathrm{C}$ (5-3.5 cal kyr BP). Testacean, chironomid and diatom data of the lake deposits recorded decreasing water level, and diatom-based $\mathrm{pH}$ reconstructions vary between 6.9 and 8 over time. After disappearance of the lake at about $3.5 \mathrm{cal}$ kyr BP, paludification of the lake's basin promoted talik refreezing and pingo growth. Stable water isotope and hydrochemical signatures have recorded two types of massive ground ice. The pingo ice isotopic signature points to the initial stage of closed-system freezing with a slope of 5.85. Within the pingo ice, a second ice type was observed with more depleted values in $\delta^{18} \mathrm{O}$ and $\delta \mathrm{D}$ and a slope of 8.13. This ice might have formed as infill of dilation cracks by surface water with quasi-meteoric isotopic composition. The late Holocene wedge-ice $\delta^{18} \mathrm{O}$ average value was about $-26.6 \%$; moisture source is assumed to derive mainly from the Pacific Ocean.

On the one hand, climate warming in the early Holocene has caused thermokarst lake formation. On the other, late Holocene cooling, talik refreezing and environmental changes such as peat accumulation have led to permafrost aggradation (ie, pingo and wedge-ice development), thus further intensifying a small-scale landscape mosaic of lakes, pingos and polygonal ground with strong environmental gradients.

\section{ACKNOWLEDGEMENTS}

Members of the Arbatsky family, Liudmila Pestryakova and Mikhail Cherosov (North Eastern Federal University Yakutsk), Viktor Sitalo (St Petersburg State Pedagogical Herzen University), and other members of the field team supported the study during fieldwork in 2012

in the Pokhodsk area. We acknowledge Caroline Höpfner wedge-ice growth during the different stages of the Holocene is 
(Department of Geography, Humboldt University Berlin, Germany), Dyke Scheidemann, Antje Eulenburg, Lutz Schönicke and Mikaela Weiner (all AWI Potsdam) for laboratory work. The study was part of the German-Russian joint project Polygons in tundra wetlands: state and dynamics under climate variability in tundra regions (Russian Foundation of Basic Research, RFBR grant no. 11-04-91332-NNIO-a and Deutsche Forschungsgemeinschaft, DFG grant no. HE 3622/161). The study contributes to the Arctic Ecological Network (Arc-EcoNet) funded by the German Federal Ministry of Education and Research (BMBF grant no. 01DJ14003 to S.W.). Testacean analysis was supported by RFBR (grant nos. 16-04-00451-a and 15-29-02518 to A.B.). Pollen analysis was carried out at St Petersburg State University (grant no. 18.40.68.2017 to L.S.). Chironomid analysis was supported by DFG (grant no. NA 760/5-1 to L.N.) and Russian Science Foundation (RSF grant no. 16-17-10118 to L.N.). T.O. and S.W. acknowledge funding from DFG (grant no. OP 217/3-1 and WE4390/7-1, respectively). The ArcticDEM was provided by the Polar Geospatial Center under NSF OPP awards 1043681, 1559691 and 1542736. We acknowledge Copernicus Sentinel Data 2017. The data presented in this paper are available at PANGAEA ${ }^{74}$ (https://doi.org/ 10.1594/PANGAEA.884369). We acknowledge one anonymous reviewer and Mikhail Kanevskiy (University of Alaska Fairbanks) for critical and helpful suggestions, which improved the final version of the paper.

\section{ORCID}

Sebastian Wetterich (i) http://orcid.org/0000-0001-9234-1192

Michael Fritz (D) http://orcid.org/0000-0003-4591-7325

Thomas Opel (D) http://orcid.org/0000-0003-1315-8256

\section{REFERENCES}

1. Shur YL, Jorgenson MT. Patterns of permafrost formation and degradation in relation to climate and ecosystems. Permafr Periglac Process. 2007;18(1):7-19.

2. Anthony KM, Zimov SA, Grosse G, et al. A shift of thermokarst lakes from carbon sources to sinks during the Holocene epoch. Nature. 2014;511(7510):452-456.

3. Koven CD, Schuur EAG, Schädel C, et al. A simplified, data-constrained approach to estimate the permafrost carbon-climate feedback. Phil Trans R Soc A. 2015;373(2054):20140423

4. Mackay JR. Pingo ice of the western Arctic coast, Canada. Can J Earth Sci. 1985;22(10):1452-1464.

5. van Everdingen RE. Multi-language glossary of permafrost and related ground-ice terms (revised 2005). Boulder, USA: National Snow and Ice Data Center/World Data Center for Glaciology:1998.

6. Mackay JR. Pingos of the Pleistocene Mackenzie Delta area. Geogr Bull. 1962;18:21-63.

7. Yoshikawa K, Leuschen C, Ikeda A, et al. Comparison of geophysical investigations for detection of massive ground ice (pingo ice). J Geophys Res. 2006;111:E06S19.

8. Jones BM, Grosse G, Hinkel KM, et al. Assessment of pingo distribution and morphometry using an IfSAR derived DSM, western Arctic Coastal Plain, northern Alaska. Geomorphology. 2012;138(1):1-14.

9. Flemal RC. Pingos and pingo scars: their characteristics, distribution, and utility in reconstructing former permafrost environments. Quatern Res. 1976;6(1):37-53.

10. Mackay JR. Growth of Ibyuk Pingo, western Arctic coast, Canada, and some implications for environmental reconstructions. Quatern Res. 1986;26(1):68-80.
11. Walker MD, Everett KR, Walker DA, Birkeland PW. Soil development as an indicator of relative pingo age, Northern Alaska, USA. Arct Alp Res. 1996;28(3):352-362.

12. Grosse G, Schirrmeister L, Siegert C, et al. Geological and geomorphological evolution of a sedimentary periglacial landscape in northeast Siberia during the late Quaternary. Geomorphology. 2007;86(1-2):25-51.

13. Hyvärinen H, Ritchie JC. Pollen stratigraphy of Mackenzie pingo sediments, N.W.T., Canada. Arct Alp Res. 1975;7(3):261-272.

14. Wetterich S, Grosse G, Schirrmeister L, et al. Late Quaternary environmental and landscape dynamics revealed by a pingo sequence on the northern Seward Peninsula, Alaska. Quat Sci Rev. 2012;39:26-44.

15. Palagushkina O, Wetterich S, Biskaborn BK, et al. Diatom records and tephra mineralogy in pingo deposits of Seward Peninsula, Alaska. Palaeogeogr Palaeoclimatol Palaeoecol. 2017;479:1-15.

16. Ulrich M, Wetterich S, Rudaya N, et al. Rapid thermokarst evolution during the mid-Holocene in Central Yakutia, Russia. Holocene. 2017;27(12):1899-1913.

17. Grosse G, Jones BM. Spatial distribution of pingos in northern Asia. Cryosphere. 2011;5(1):13-33.

18. Schirrmeister L, Pestryakova L, Schneider A, Wetterich S (Eds). Studies of polygons in Siberia and Svalbard. Rep Pol Mar Res. 2016;697:1-275.

19. Andreev AV. Wetlands in Northeastern Russia (Wetlands in Russia, Volume 4). Moscow, Russia: WWF, Wetlands International Programme; 2001, 2001.

20. Nikanorov AM, Bryzgalo VA, Kosmenko LS, Reshetnyak OS. The Kolyma River mouth area under present conditions of anthropogenic impact. Russ Meteorol Hydrol. 2011;36(8):549-558.

21. Auslov BN, Potshova MN, Ivanenko GV. Map of pre Quaternary deposits (R-(55)-57 Nizhnekolymsk), scale 1:1,000,000. State Geological Map of the Russian Federation. Moscow, Russia: Ministry of Natural Resources of the Russian Federation; 1998.

22. Ivanenko GV. Map of Quaternary formations, scale 1: 1,00,000. State Geological Map of the Russian Federation (New Series). Moscow, Russia: Ministry of Natural Resources of the Russian Federation, Cartographic Company VSEGEI; 1998.

23. New M, Lister D, Hulme M, Makin I. A high-resolution data set of surface climate over global land areas. Climate Res. 2002;21:1-25.

24. Yershov ED, Kondratyeva KA, Zamolotchikova SA, Trush NI, YeN D. Geocryological map of Russia and neighboring republics, scale 1:2,500,000. Moscow, Russia: Moscow State University, Russian Ministry of. Geology. 1999.

25. de Klerk $P$, Theuerkauf $M$, Joosten $H$. Vegetation, recent pollen deposition, and distribution of some non-pollen palynomorphs in a degrading ice-wedge polygon mire complex near Pokhodsk (NE Siberia), including size-frequency analyses of pollen attributable to Betula. Rev Palaeobot Palynol. 2017;238:122-143.

26. Kienast F. Studies of modern vegetation and sampling of permafrost deposits for palaeobotanical studies at the lower Kolyma. Rep Pol Mar Res. 2016;697:87-160.

27. CAVM Team. Circumpolar Arctic vegetation map (1:7,500,000 scale). Conservation of Arctic Flora and Fauna (CAFF) Map No. 1. Anchorage, AK: US Fish and Wildlife Service; 2003 Accessed January 18, 2017.

28. French H, Shur Y. The principles of cryostratigraphy. EarthSci Rev. 2010;101(3-4):190-206.

29. Wetterich S, Tumskoy V, Rudaya N, et al. Ice Complex permafrost of MIS5 age in the Dmitry Laptev Strait coastal region (East Siberian Arctic). Quat Sci Rev. 2016;147:298-311.

30. Reimer PJ, Bard E, Bayliss A, et al. IntCal13 and Marine13 radiocarbon age calibration curves $0-50,000$ years cal BP. Radiocarbon. 2013;55(4):1869-1887.

31. Blaauw M, Christen JA. Flexible paleoclimate age-depth models using an autoregressive gamma process. Bayesian Anal. 2011;6(3):457-474. 
32. Fritz $\mathrm{M}$, Wolter J, Rudaya $\mathrm{N}$, et al. Holocene ice-wedge polygon development in the northern Yukon, Canada. Quat Sci Rev. 2016;147:279-297.

33. Meyer H, Schönicke L, Wand U, Hubberten HW, Friedrichsen $H$. Isotope studies of hydrogen and oxygen in ground ice-experiences with the equilibration technique. Isotopes Environ Health Stud. 2000;36(2):133-149.

34. Dansgaard W. Stable isotopes in precipitation. Tellus. 1964:16:436-468.

35. Suzuki R, Shimodaira H. pvclust: hierarchical clustering with $p$-values via multiscale bootstrap resampling; 2015. http://www.sigmath.es. osaka-u.ac.jp/shimo-lab/prog/pvclust/. Accessed October 25, 2017.

36. Berglund BE, Ralska-Jasiewiczowa M. Pollen analysis and pollen diagram. In: Berglund BE, ed. Handbook of Holocene Palaeoecology and Palaeohydrology. New York, NY: Wiley Interscience; 1986:455-484.

37. Moore PD, Webb JA, Collinson ME. Pollen Analysis. Oxford, UK: Blackwell Scientific; 1991.

38. Savelieva LA, Raschke EA, Titova DV. Photographic atlas of plants and pollen of the Lena River Delta. St. Petersburg, Russia: St. Petersburg State University; 2013 (in Russian).

39. Chardez D. Ecologie générale des Thécamoebiens. Bulletin Institut Agronomique et des Stations de Recherche de Gembloux. 1965;33:307-341. (in French)

40. Bobrov AA, Wetterich S, Beermann F, et al. Testate amoebae and environmental features of polygon tundra in the Indigirka lowland (East Siberia). Polar Biol. 2013;36(6):857-870.

41. Battarbee RW, Jones VJ, Flower RJ, et al. Diatoms. In: Smol JP, Birks HJB, Last WM, eds. Tracking Environmental Change Using Lake Sediments. Dordrecht, The Netherlands: Kluwer Academic Publishers; 2001:155-202.

42. Krammer K, Lange-Bertalot H. Bacillariophyceae, vol. 2 (1-4). In: Ettle H, Gerloff J, Heyning H, Mollenhauer D, eds. Süsswasserflora von Mitteleuropa. Stuttgart, Germany: Gustav Fischer Verlag:1986-1991 (in German).

43. Guiry MD, Guiry GM. AlgaeBase. Galway, Ireland: National University of Ireland; 2017 http://www.algaebase.org. Accessed January 18, 2017.

44. Barinova SS, Medvedeva LA, Anisimova OV. Biodiversity of Algae-Indicators of the Environment. Tel Aviv, Israel: Pilies Studio; 2006 (in Russian).

45. Magurran E. Ecological Diversity and Its Measurement. Princeton, NJ: Princeton University Press; 1992.

46. European Diatom Database. European Diatom Database Newcastle upon Tyne, UK: Newcastle University; 2001. http://craticula.ncl.ac. uk/Eddi/jsp/. Accessed January 18, 2017,

47. Brooks SJ, Birks HJB. Chironomid-inferred late-glacial and earlyHolocene mean July air temperatures for Krákenes Lake, western Norway. J Paleo. 2000;23(1):77-89.

48. Wiederholm T. Chironomidae of the Holarctic region. Keys and diagnoses. Part 1. Larvae. Entomol Scand Suppl. 1983;19:1-457.

49. Brooks SJ, Langdon PG, Heiri O. Using and identifying chironomid larvae in palaeoecology. In: QRA Technical Guide No. 10. London, UK: Quaternary Research Association; 2007.

50. Nazarova L, Herzschuh U, Wetterich S, Kumke T, Pestryakova L. Chironomid-based inference models for estimating mean July air temperature and water depth from lakes in Yakutia, northeastern Russia. $J$ Paleo. 2011;45(1):57-71.

51. Nazarova L, Self AE, Brooks SJ, van Hardenbroek M, Herzschuh U, Diekmann B. Northern Russian chironomid-based modern summer temperature data set and inference models. Global Planet Change. 2015;134:10-25.

52. Hill MO. Diversity and evenness: a unifying notation and its consequences. Ecology. 1973;54(2):427-432.
53. Biskaborn BK, Herzschuh U, Bolshiyanov DY, Schwamborn G, Diekmann B. Thermokarst processes and depositional events in a tundra lake, Northeastern Siberia. Permafrost Periglac Process. 2013;24(3):160-174

54. Meyers PA. Organic geochemical proxies of paleoceanographic, paleolimnologic, and paleoclimatic processes. Org Geochem. 1997;27(5-6):213-250.

55. Lenz J, Wetterich S, Jones BM, Meyer H, Bobrov A, Grosse G. Evidence of multiple thermokarst lake generations from an 11800 year-old permafrost core on the northern Seward Peninsula, Alaska. Boreas. 2016;45(4):584-603.

56. Klemm J, Herzschuh U, Pisaric MFJ, Telford RJ, Heim B, Pestryakova LA. A pollen-climate transfer function from the tundra and taiga vegetation in Arctic Siberia and its applicability to a Holocene record. Palaeogeogr Palaeoclimatol Palaeoecol. 2013;386:702-713.

57. Biskaborn BK, Subetto DA, Savelieva LA, et al. Late Quaternary vegetation and lake system dynamics in north-eastern Siberia: implications for seasonal climate variability. Quat Sci Rev. 2016;147:406-421.

58. Ishikawa $M$, Yamkhin J. Formation chronology of Arsain pingo, Darhad Basin, Northern Mongolia. Permafrost Periglac Process. 2016;27(3):297-306

59. Vasil'chuk YK, Lawson DE, Yoshikawa K, et al. Stable isotopes in the closed-system Weather Pingo, Alaska and Pestsovoye Pingo, northwestern Siberia. Cold Reg Sci Technol. 2016;128:13-21.

60. Yoshikawa K, Sharkhuu N, Sharkhuu A. Groundwater hydrology and stable isotope analysis of an open-system pingo in northwestern Mongolia. Permafrost Periglac Process. 2013;24(3):175-183.

61. Lacelle $\mathrm{D}$. On the $\delta^{18} \mathrm{O}, \delta \mathrm{D}$ and $\mathrm{D}$-excess relations in meteoric precipitation and during equilibrium freezing: theoretical approach and field examples. Permafrost Periglac Process. 2011;22(1):13-25.

62. Jouzel J, Souchez RA. Melting and refreezing at the glacier sole and the isotopic composition of the ice. J Glaciol. 1982;28(98):35-42.

63. Souchez RA, Jouzel J, Lorrain R, Sleewaegen S, Stiévenard M, Verbeke $\mathrm{V}$. A kinetic isotope effect during ice formation by water freezing. Geophys Res Lett. 2000;27(13):1923-1926.

64. Fritz M, Wetterich S, Meyer H, Schirrmeister L, Lantuit H, Pollard WH. Origin and characteristics of massive ground ice on Herschel Island (Western Canadian Arctic) as revealed by stable water isotope and hydrochemical signatures. Permafrost Periglac Process. 2011;22(1):26-38.

65. Meyer H, Dereviagin A, Siegert C, Hubberten H-W. Paleoclimate studies on Bykovsky Peninsula, North Siberia-hydrogen and oxygen isotopes in ground ice. Polarforschung. 2002;70:37-51.

66. Chizhov AB, Dereviagin A, Simonov EF, Hubberten H-W, Siegert C. Isotope composition of ground ice in the area of Labaz Lake (Taimyr). Kriosfera Zemli. 1997;1:79-84. (in Russian)

67. Wetterich S, Kuzmina S, Andreev AA, et al. Palaeoenvironmental dynamics inferred from late Quaternary permafrost deposits on Kurungnakh Island (Lena Delta, Northeast Siberia, Russia). Quat Sci Rev. 2008;27(15-16):1523-1540.

68. Meyer H, Opel T, Laepple T, Dereviagin AY, Hoffmann K, Werner M. Long-term winter warming trend in the Siberian Arctic during the mid- to late Holocene. Nat Geosci. 2015;8(2):122-125.

69. Opel T, Wetterich S, Meyer H, Dereviagin AY, Fuchs MC, Schirrmeister L. Ground-ice stable isotopes at the Oyogos Yar Coast (Dmitry Laptev Strait)-indications for Late Quaternary paleoclimate in the Northeast Siberian Arctic. Clim Past. 2017;13(6):587-611.

70. Veremeeva A, Gubin S. Modern tundra landscapes of the Kolyma Lowland and their evolution in the Holocene. Permafrost Periglac Process. 2009;20(4):399-406.

71. Veremeeva AA, Glushkova NV. Formation of relief in the regions of Ice Complex deposits distribution: remote sensing and GIS studies in the Kolyma Lowland tundra. Kriosfera Zemli. 2016;20:14-24. 
72. Nitze I, Grosse G, Jones BM, et al. Landsat-based trend analysis of lake dynamics across Northern permafrost regions. Remote Sen. 2017;9(7):640.

73. Schwamborn G, Rachold V, Grigoriev MN. Late Quaternary sedimentation history of the Lena Delta. Quat Int. 2002;89(1):119-134.

74. Wetterich S, Meyer H, Nazarova LB, et al. Sediment, ground ice and micropaleontological data from the pingo exposure "Shirokovsky Kholm" (Kolyma Lowland, NE Siberia) sampled in 2012. Pangaea. 2017. https://doi.org/10.1594/PANGAEA.884369

\section{SUPPORTING INFORMATION}

Additional supporting information may be found online in the Supporting Information section at the end of the article.

How to cite this article: Wetterich S, Schirrmeister L, Nazarova L, et al. Holocene thermokarst and pingo development in the Kolyma Lowland (NE Siberia). Permafrost and Periglac Process. 2018;1-17. https://doi.org/10.1002/ ppp.1979 